\title{
WATER QUALITY OF ROGERS LAKE, DAKOTA COUNTY, MINNESOTA
}

U. S. GEOLOGICAL SURVEY

Water-Resources Investigations 80-5

Prepared in cooperation with

Minnesota Department of Transportation 


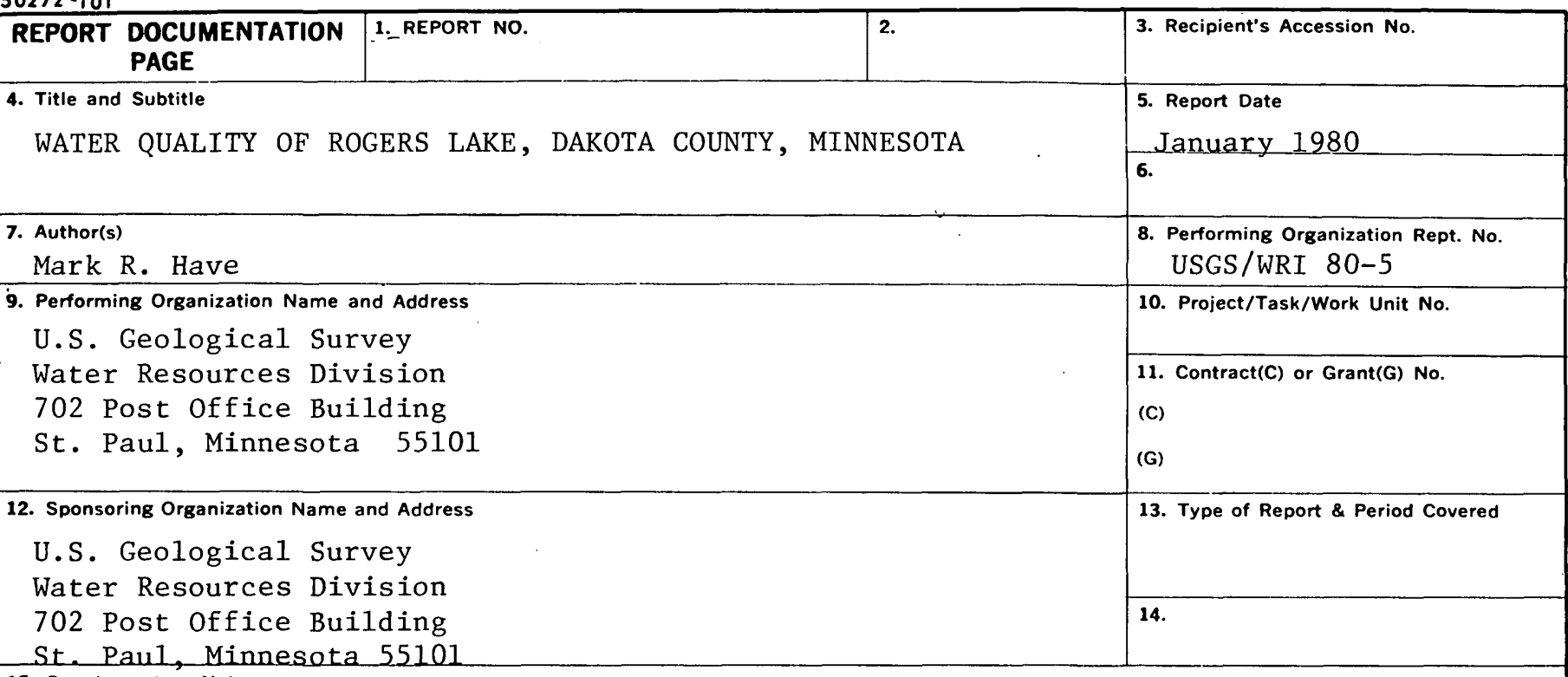

15. Supplementary Notes

Prepared in cooperation with the Minnesota Department of Transportation

16. Abstract (Limit: 200 words)

Construction of an interstate highway is planned near Rogers Lake in Dakota County, Minn. Samples of water and bed material were collected at six sites during March 1976 to April 1978 to determine selected physical, chemical, and biological characteristics before construction. Samples were collected at least twice during each season of the year. Data derived from these samples will provide baseline information to aid in assessing the impact of highway construction on the water quality of the lake. Rogers Lake is separated into an upper and lower lake by a culvert; both were eutrophic and dominated by blue-green algae year around.

Analyses of water from Rogers Lake suggest that sodium and chloride concentrations were higher than in ground water or in water in some surrounding 1akes. Sodium ranged from 7.2 to 55 milligrams per liter, and chloride ranged from 15 to 30 milligrams per 1 iter. Concentrations were highest in March 1978, when most of the lake water was frozen. Much of the sodium and chloride may have been derived from road salts used for deicing.

17. Document Analysis a. Descriptors

*Lakes, *Limnology, *Water quality, Biological properties, Chemical properties, Eutrophication, Aquatic algae, Enteric bacteria

b. Identifiers/Open-Ended Terms

*Dakota County, *Minnesota

c. COSATI Field/Group

18. Availability Statement

No restriction on distribution

\begin{tabular}{|l|l|}
\hline 19. Security Class (This Report) & $\begin{array}{l}\text { 21. No. of Pages } \\
39\end{array}$ \\
\hline 20. Security Class (This Page) & 22. Price \\
\hline & $\begin{array}{l}\text { OPTIONAL FORM 272 (4-77) } \\
\text { (Formerly NTIS-35) } \\
\text { Department of Commerce }\end{array}$
\end{tabular}


WATER QUALITY OF. ROGERS LAKE,

DAKOTA COUNTY, MINNESOTA

By M. R. Have

U.S. GEOLOGICAL SURVEY

Water-Resources Investigations $80-5$

Prepared in cooperation with

Minnesota Department of Transportation 
UNITED STATES DEPARTMENT OF THE INTERIOR

CECII D. ANDRUS, Secretary

GEOLOG ICAL SURVEY

H. William Menard, Director

For additional information write to:

U.S. Geological Survey

702 Post Office Bullding

St. Paul, Minnesota 55101 
Page

Conversion factors................................... iv

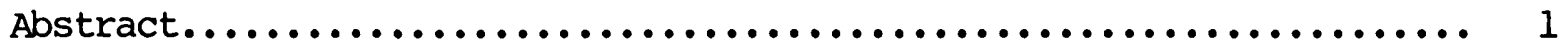

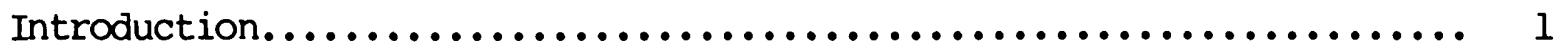

Envionmental setting................................... 1

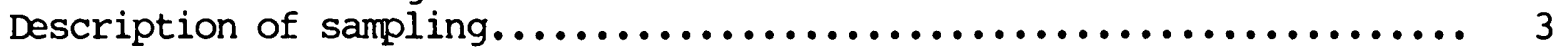

Results and discussion.................................. 4

Major chemical constituents........................... 4

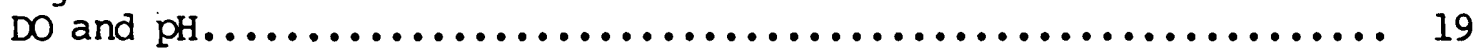

Selected trace metals................................. 19

Nutrients........................................... 25

Biological characteristics............................ 28

Other characteristics.............................. 32

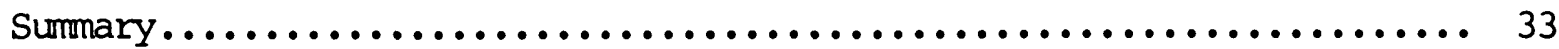

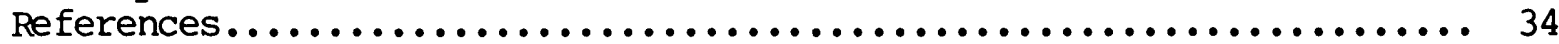

\section{ILLUSTRATIONS}

Figure 1. Map showing sampling sites at Rogers Lake.............. 2

2. Graphs of water type for each sampling site at Rogers

Lake........................................ 5

3-5. Graphs showing

3. Chloride concentrations for each sampling site at

Rogers Lake................................ 18

4. Dissolved-oxygen concentrations and $\mathrm{pH}$ for each sampling site at Rogers Lake................... 24

5. Total and dissolved-phosphorus concentrations for each sampling site at Rogers Lake............... 26

\section{TABLES}

Table 1. Analyses of regularly sampled parameters from Rogers Lake,

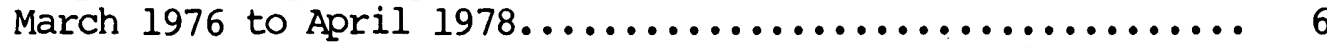

2. Averages and ranges of specific conductance and dissolved solids for each sampling site at Rogers Lake............ 16

3. Mean equivalent proportions of calcium, magnesium, sodium, and chloride for each sampling site at Rogers Lake........ 17

4. Oil and grease, nutrients, and selected trace metals in bottom sediments for each sampling site at Rogers Lake..... 20 


\section{TABLES-Continued}

Table 5. Selected trace metals in water for each sampling site at Rogers Lake...................................... 22

6. Average nitrogen, phosphorus, 'silica, anä organic carbon concentrations for each sampling site at Rogers Lake....... 27

7. Phytoplankton concentrations and dominant and codominant genera for each sampling site at Rogers Lake............. 29

8. Number of occurrences of blue-green algae for each sampling site at Rogers Lake, March 1976 to April 1978.

Multiply

inch-pound unit

acre

foot ( ft)

inch (in)
By

0.4047

.3048

25.4
To obtain SI units

hectare (ha)

meter $(\mathrm{m})$

millimeter (mm) 
WATER QUALITY OF ROGERS LAKE, DAKOTA COUNTY, MINNESOTA

By M. R. Have

\section{ABSTRACT}

Construction of an interstate highway is planned near Rogers Lake in Dakota County, Minn. Samples of water and bed material were collected at six sites during March 1976 to April 1978 to determine selected physical, chemical, and biological characteristics before construction. Samples were collected at least twice during each season of the year. Data derived from these samples will provide baseline information to aid in assessing the impact of highway construction on the water quality of the lake.

Rogers Lake is separated into an upper and lower lake by a culvert; both were eutrophic and dominated by blue-green algae year around. The upper lake is a closed basin; it is shallower and contains less water than the lower lake and had higher concentrations of dissolved solids, nitrogen, and phosphorus. Phytoplankton cell counts were also higher in the upper lake.

Analyses of water from Rogers Lake suggest that sodium and chloride concentrations were higher than in ground water or in water in some surrounding lakes. Sodium ranged from 7.2 to 55 milligrams per liter, and chloride ranged from 15 to 130 milligrams per liter. Concentrations were highest in March 1978, when most of the lake water was frozen. Much of the sodium and chloride may have been derived from road salts used for deicing.

\section{INTRODUCTION}

Construction of Interstate Highway I-35E near Rogers Lake in Dakota County, Minn. (fig. 1) has been proposed by the Minnesota Department of Transportation. As part of an environmental impact study, a water-quality assessment during preconstruction, construction, and post-construction phases is planned. The purpose of this study is to provide preconstruction water-quality data for Rogers Lake.

\section{ENVIRONMENTAL SETTING}

Rogers Lake is in the Twin Cities Metropolitan Area in the municipality of Mendota Heights. The lake fills an ice-block depression in till of the St. Croix moraine formed during Wisconsin Glaciation (Bray, 1977).

Rogers Lake has a surface area of 116 acres and is divided into an upper and lower lake by Dakota County Road 16 (fig. 1). A culvert under the road connects the lakes, but it was plugged during the time of the study. Rogers Lake is, in effect, two separate lakes (hereafter Rogers Lake or "the lake" refers to both). 


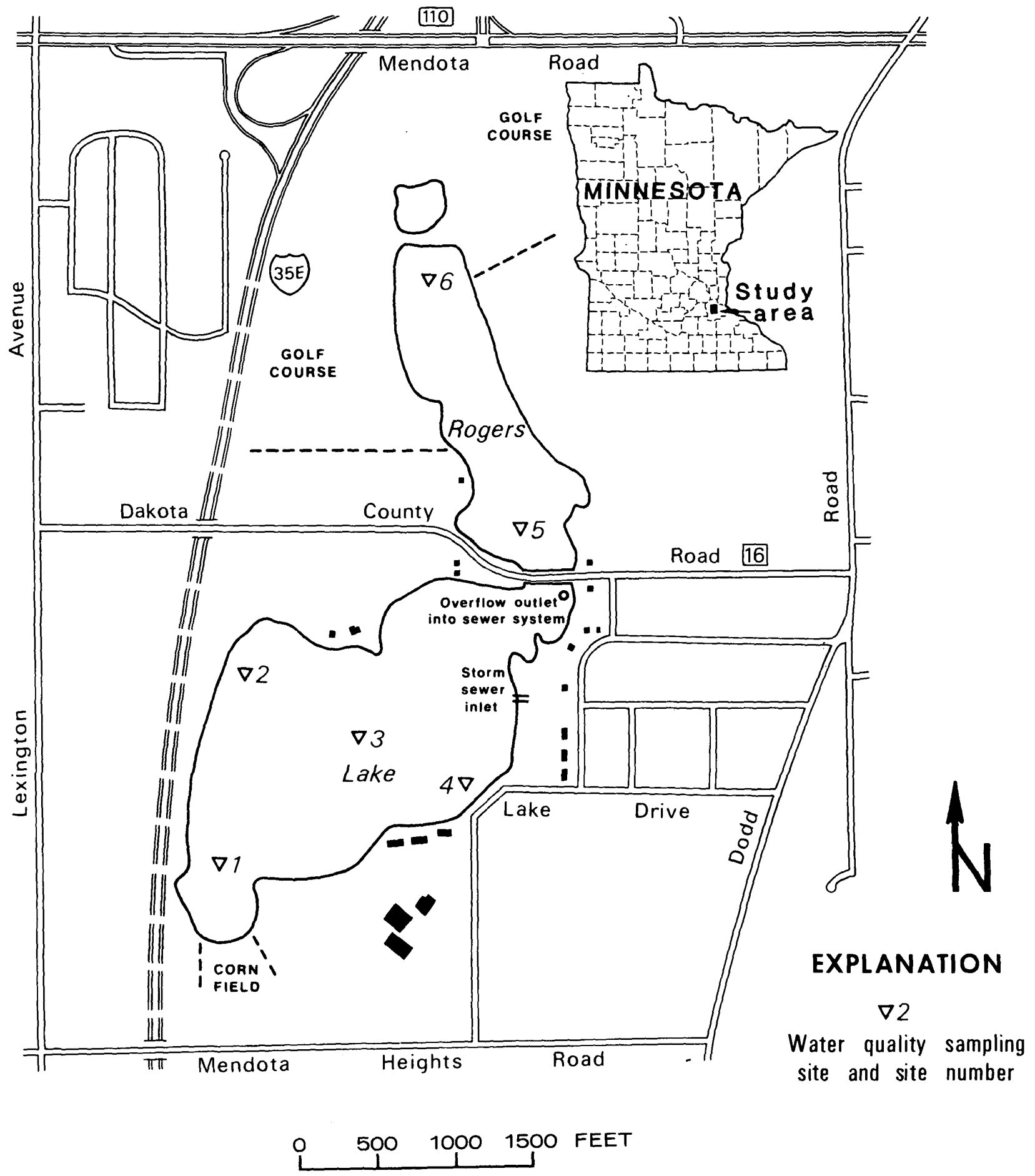

Figure 1.--Sampling sites at Rogers Lake, Dakota County 
Rogers Lake has no natural surface-water inlets or outlets; however, the lower lake receives water from a storm-sewer inlet on the east side (fig. 1). This storm sewer drains the residential area immediately east of the lake. An overflow at the northeast corner of the lower lake empties into the municipal sewer system.

The area around Rogers Lake is moderately developed (fig. 1). A golf course borders most of the upper lake; the remaining area around the upper lake is swampland. The intersection of State Highway 110 and Interstate I-35E is about 1,300 feet from the upper lake. Several houses and an apartment complex are on the east side of the lower lake. When completed, Interstate I-35E will border the western edge of the lower lake.

\section{DESCRIPTION OF SAMPLING}

Samples were collected at the six sampling sites shown in figure 1 in late winter, spring, summer, and autumn. Grab samples were collected near the water surface at each site.

When sampling began in March 1976, characteristics determined in the field included depth at sampling site, pH, specific conductance, DO (dissolved oxygen), water and air temperatures, and Secchi-disk transparency. Fecal coliform and fecal Streptococci bacteria, phytoplankton, major cations and anions, nutrients, oil and grease, turbidity, suspended solids, and dissolved solids were measured in the laboratory. During the autumn sampling, additional determinations were made for selected trace metals in the water, and selected trace metals, nutrients, and oil and grease were determined in the bottom sediments. The bottom sediments were collected with a U.S. BMH60 scoop-type samplex that collects sediment to a depth of 1.7 inches.

In July 1977, detergents, selenium, cyanide, fluoride, BOD (biochemical oxygen demand), and COD (chemical oxygen demand) were added to the sampling schedule. Barium and boron were added to the trace-metals schedule, and alkalinity as carbonate and bicarbonate was determined in the field instead of in the laboratory.

The physical and chemical characteristics were determined by methods of Brown and others (1970), and Goerlitz and Brown (1972). Percentage saturation of DO was calculated according to American Public Health Association and others (1971, p. 480). Secchi-disk transparency was detemined by lowering a standard-sized Secchi disk into the water until it disappeared from view. The point of disappearance was recorded. The disk was then raised until it reappeared. The point of reappearance was recorded. The mean of the two readings was then recorded as the true reading.

Fecal coliform and fecal Streptococci bacteria were determined by the membrane-filter technique described by Greeson and others (1977). Phytoplankton concentration was also determined by the methods described by Greeson and others (1977). 


\section{RESULTS AND DISCUSSION}

\section{Major Chemical constituents}

The water in Rogers Lake is a mixed calcium bicarbonate type that contains significant amounts of sodium and chloride (fig. 2). The chloride concentrations are relatively high compared with concentrations in surrounding lakes, including lakes with storm-sewer inlets (Have, 1975, p. 21).

Sampling sites 5 and 6 in the upper lake (fig. 1) have significantly higher concentrations of calcium, magnesium, sodium, and chloride than sites 1 to 4 in the lower lake. The higher concentrations in the upper lake may be caused by (1) runoff of highway deicing salt into the upper lake from State Highway 110 , (2) runoff from irrigation of the adjacent golf course, and (3) smaller volume of water in the upper lake and, therefore, less dilution.

As seen in figure 1 , sites 5 and 6 are the closest sites to State Highway 110 and to the major intersection near the northwest corner of the lake. More road salt consisting of sodium chloride is used per mile on roads of four or more lanes and on four-lane intersections than on smaller two-lane roads (Minnesota Pollution Control Agency, 1978). The upper lake is the lowest point in a closed basin that is intersected by State Highway 110; it is approximately 30 feet lower than the major intersection. Thus, overland runoff from the highway to the lake may account for the high sodium and chloride concentrations.

The higher concentrations of calcium and magnesium at sites 5 and 6 may be partly due to cation exchange in the soil with the sodium in the road salt, although some of the calcium probably originates from the road salt itself. Divalent cations, such as calcium and magnesium, are generally held more tightly to soils (mainly clay particles) than monovalent cations, such as sodium, but the exchange process is a reversible chemical reaction that obeys the law of mass action (Hem, 1959). Hence, the massive amounts of sodium from road salt in the runoff can displace some of the calcium and magnesium ions in the soil, thereby increasing the calcium and magnesium concentrations in the water.

The golf course at the north end of the upper lake is irrigated and fertilized. Runoff from irrigation tends to be more concentrated in dissolved salts and, therefore, is a likely contributor of major ions, particularly those associated with nutrients, to the upper lake.

The higher concentrations of dissolved salts in the upper lake may also result from its being a closed basin, the smaller water volume, and the shallower depths. Much of the mineral content entering the upper lake is retained except for the amount that seeps into the ground-water system. Most dissolved minerals are concentrated in the lake water by evaporation and freezing. An example can be seen in table 1. The highest conductances and dissolved solids for sites 5 and 6 occurred in March 1978, when the average water depth of 3.5 feet at the two sites was frozen for approximately 

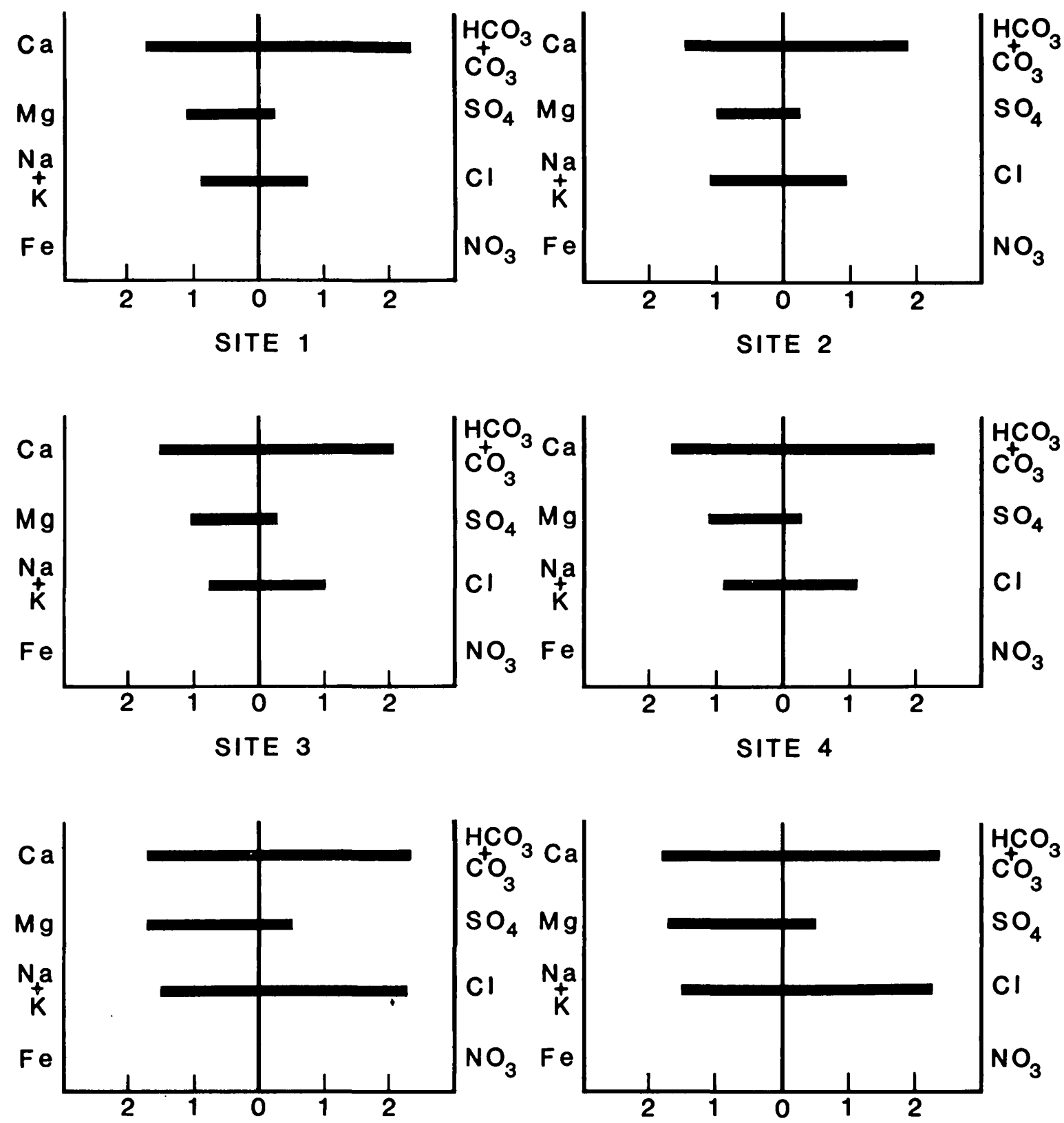

MILLIEQUIVALENTS PER LITER

SITE 5

MILLIEQUIVALENTS PER LITER

SITE 6

Figure 2.--Water type for each sampling site at Rogers Lake 
岂壳

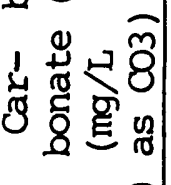

要

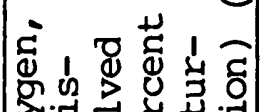

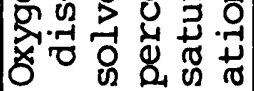

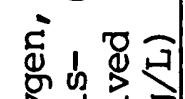

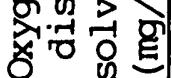

的葷。

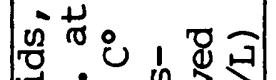

न

I

出 0 \&

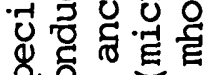

迥

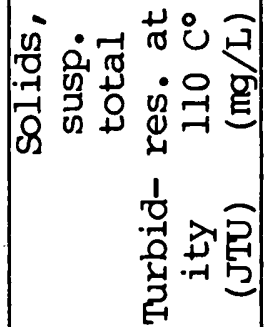

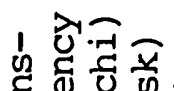

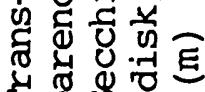

है⿴囗十

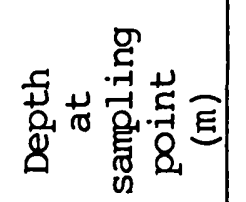

岁总㤩

$\underset{+}{+}$

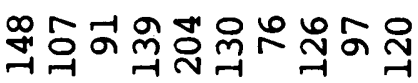

on 00000000

ஸ்

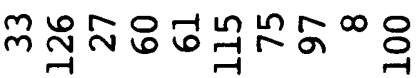

m舟

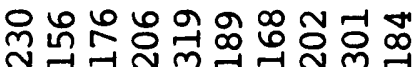

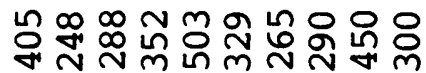

omorar NamH

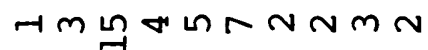

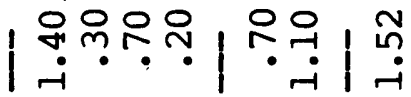

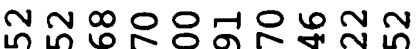

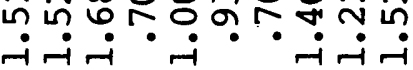

o o un o o n 0 un un 0 $\dot{m} \dot{\sim} \dot{\sim} \dot{\sim} \dot{\sim} \dot{\sim} \dot{m} \overrightarrow{-1}$

崩
:

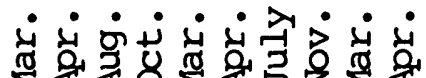

$:: \vdots: \vdots: \vdots: \vdots \vdots:$

$::: \sigma::: a$

:

กั่
ฌ্ণ

$0-10000 \underset{7}{1} 000$

mம் மீர்

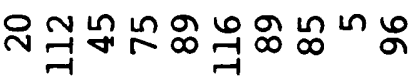

ba

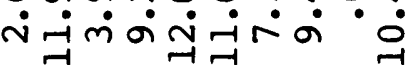

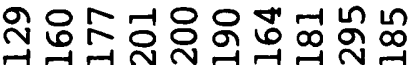

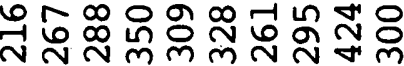

$0 \forall \underset{-}{g} m \underset{-}{N} \nabla^{m} N$

AnI

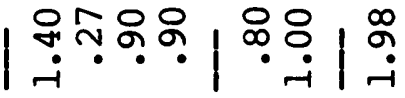

거 ๙̋ $\dot{\sim} \dot{-i} \dot{-} \dot{-} \dot{-i} \dot{-} \dot{-i}$

un un un un o un

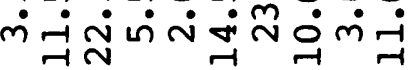

$:::::::::$ :

$::::::::: \vdots:$

ㄴ: : : : : :

ने: : :

: : : : : : :

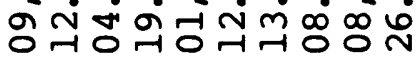

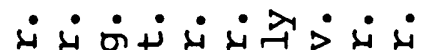

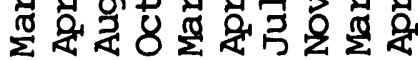




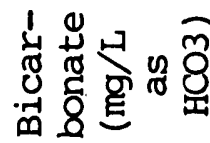

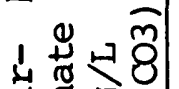

ชิ



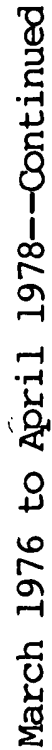

\section{in ț}

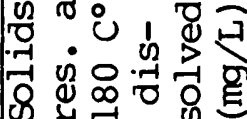

넌

出

\&ृ

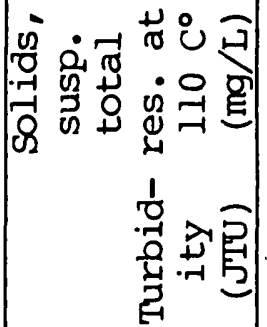

1 式.न

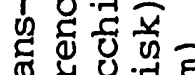

近

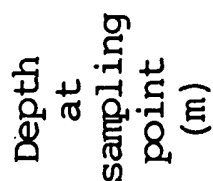

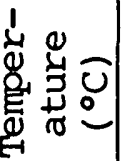

青

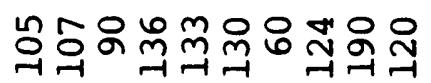

onrooom 000

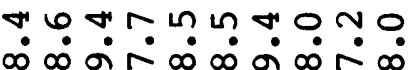

$\infty \infty \sigma r \infty \infty \operatorname{ar} \infty$

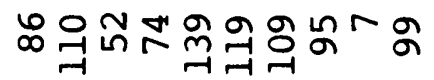

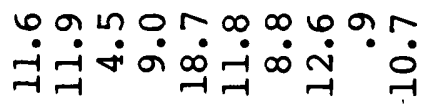

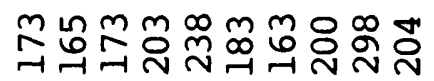

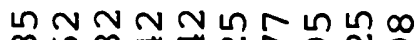
品萬出

o onar

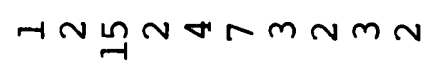

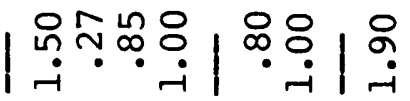

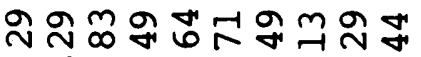
$\dot{\sim} \dot{\sim} \dot{-i} \dot{-} \dot{i} \dot{\sim} \dot{\sim}$

o o n o o o L o Ln o $\dot{\sim} \dot{\sim} \dot{\sim} \dot{\sim} \dot{\sim} \dot{\sim} \dot{m} \dot{\sim} \dot{-}$ กำ

$: \therefore:$

: $::: \vdots:: \vdots: \vdots:$

a:: :a: : :

- : :

ஸㅓㅁ

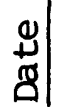

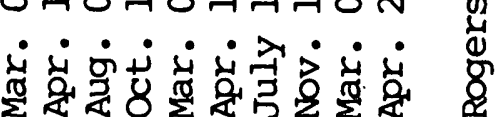

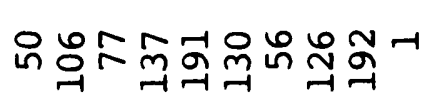

on

o.

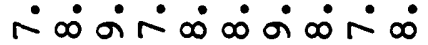

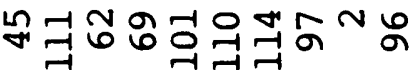

๑̆

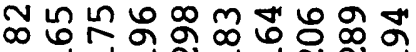

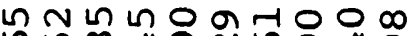

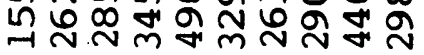

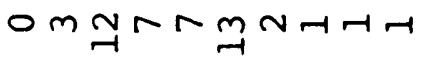

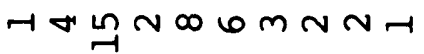

웍욤요

ڤ̊ -i்-i

000000 n 000 $\dot{\sim} \underset{\sim}{\sim} \underset{\sim}{\dot{N}} \dot{\sim} \dot{\sim} \dot{\sim} \dot{\sim} \dot{\sim}$

$::::::::::$

ம: : : : : : :

ก:: : : : : :

의:: :ब : : :

बंत்ंत்

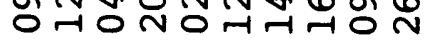

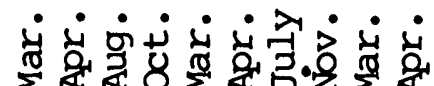




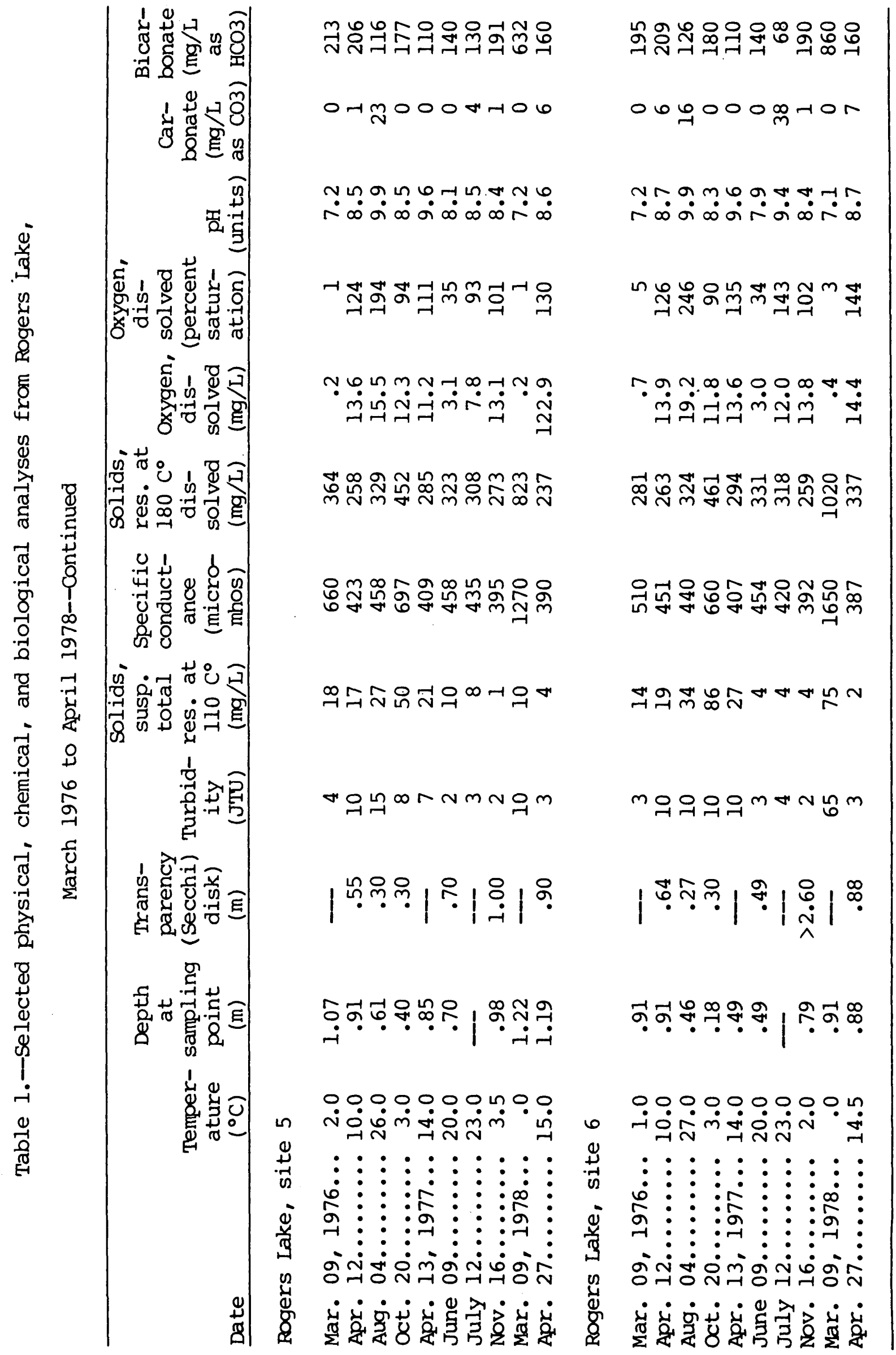




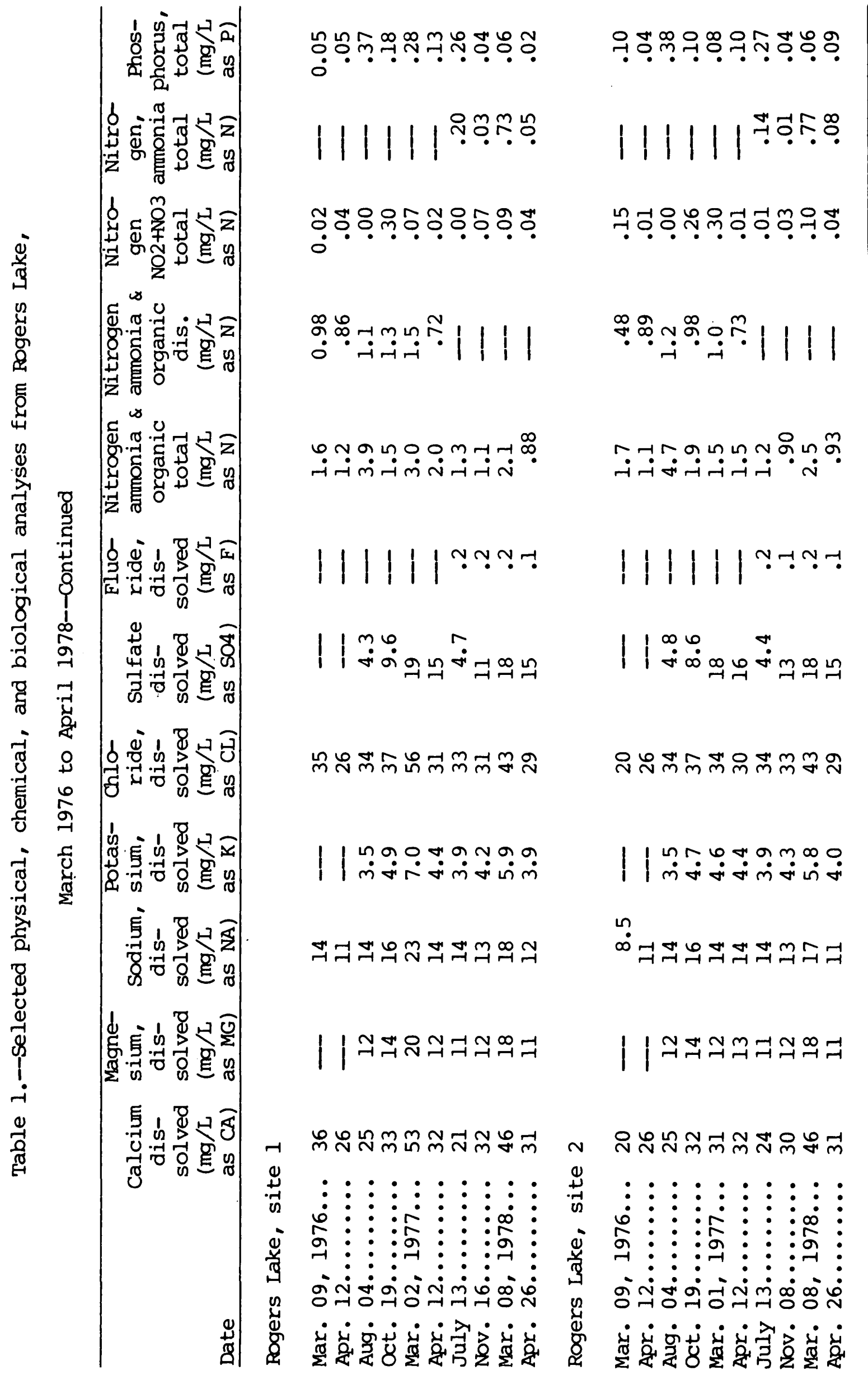




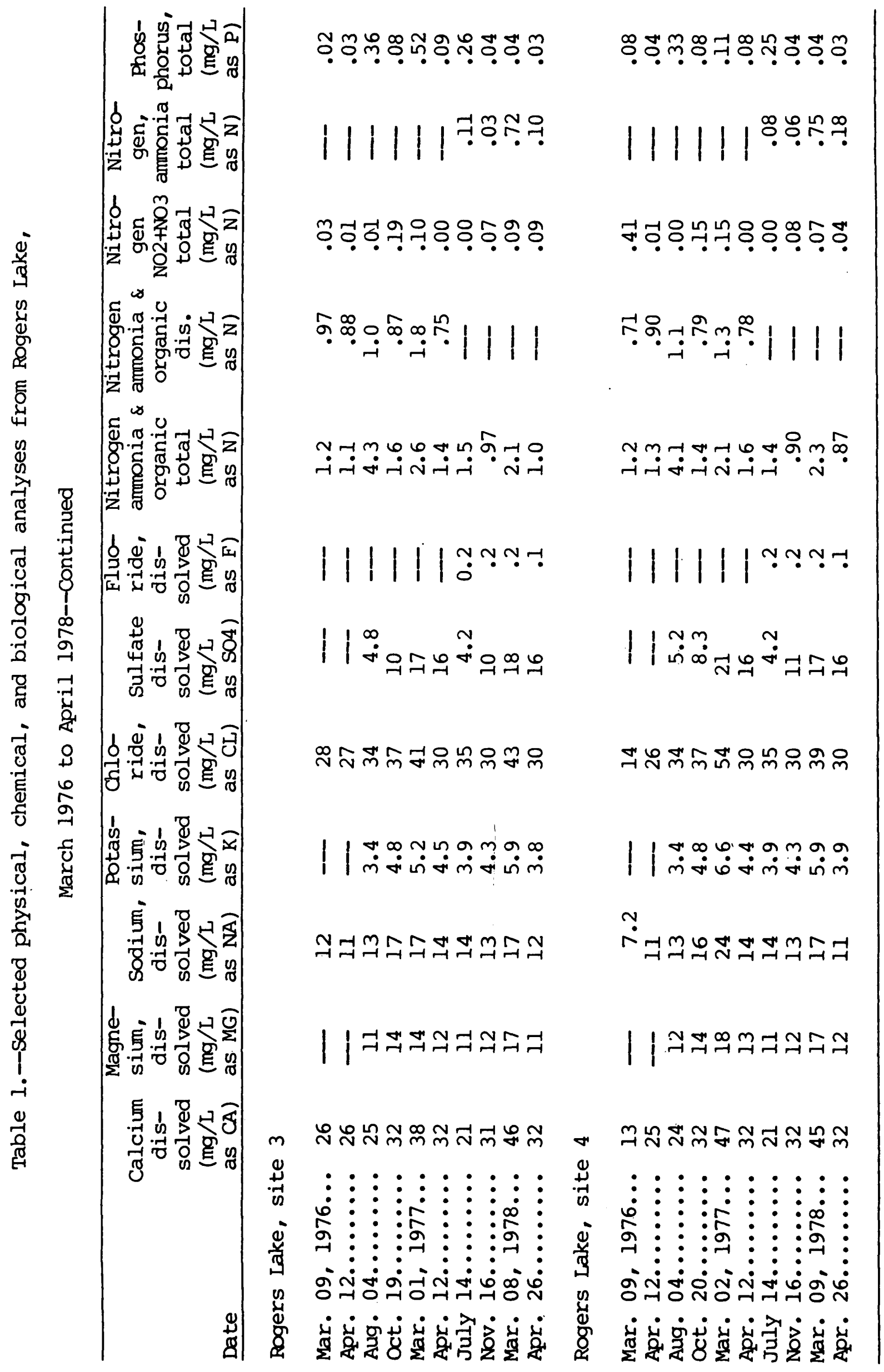




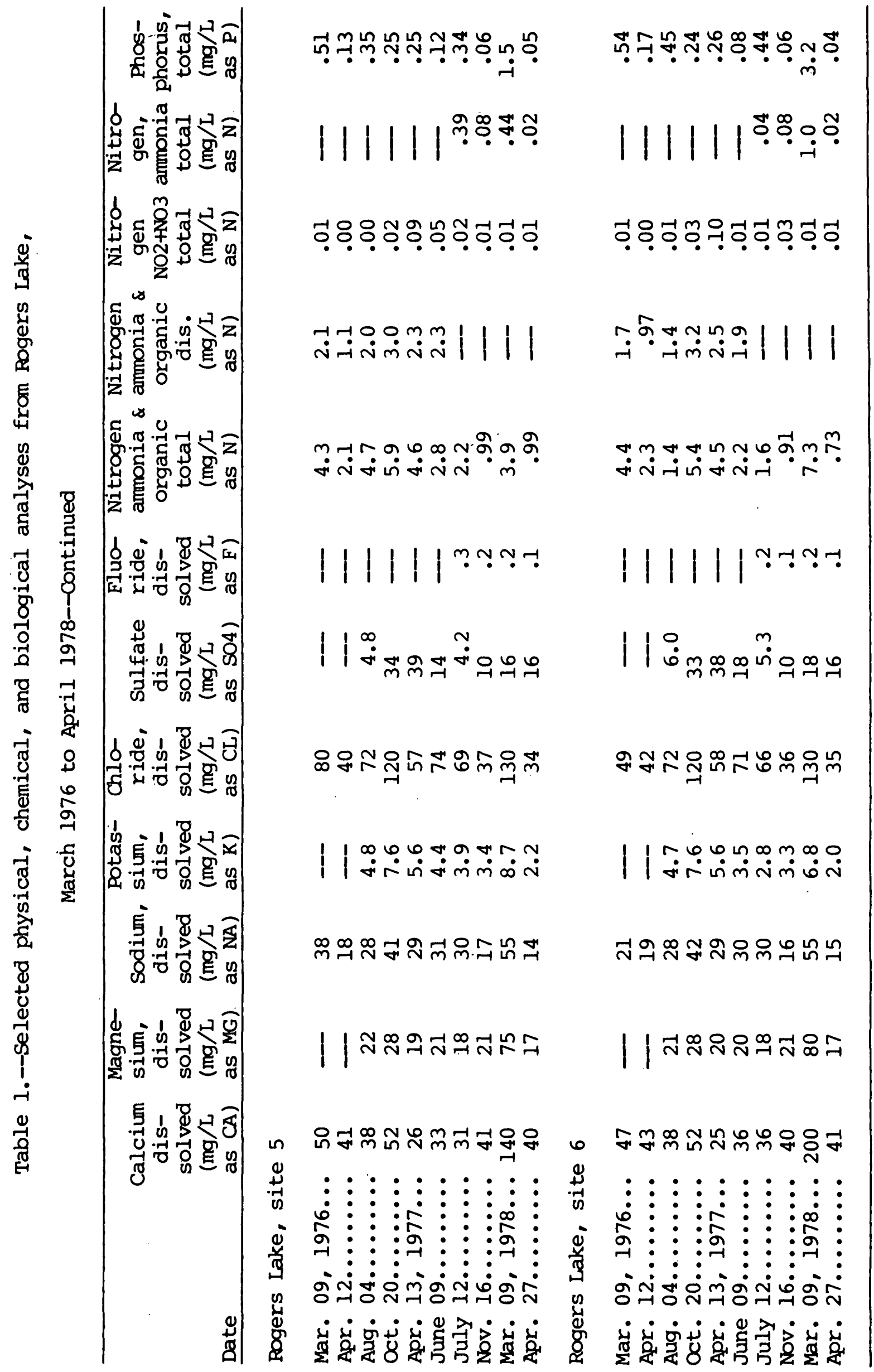




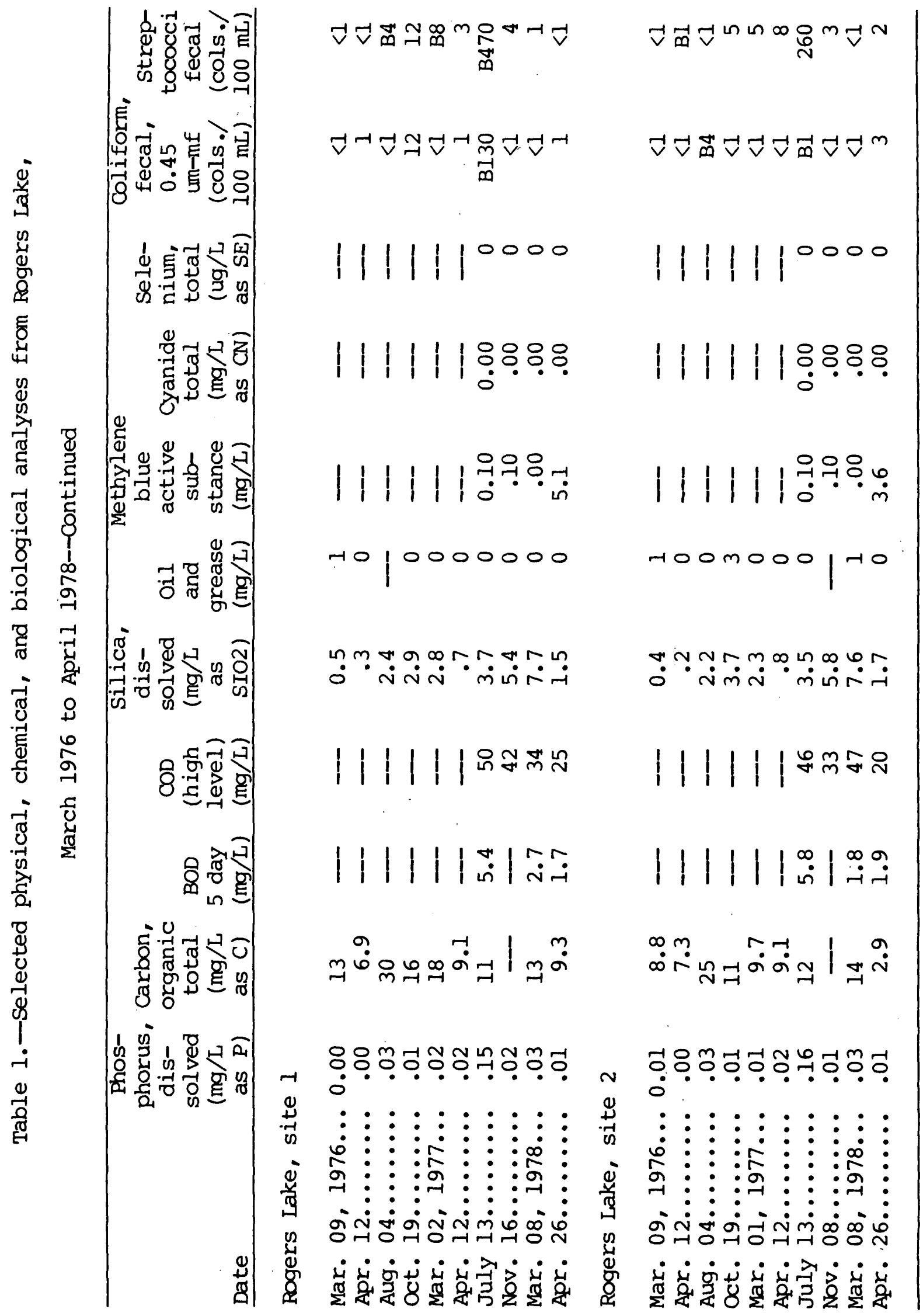




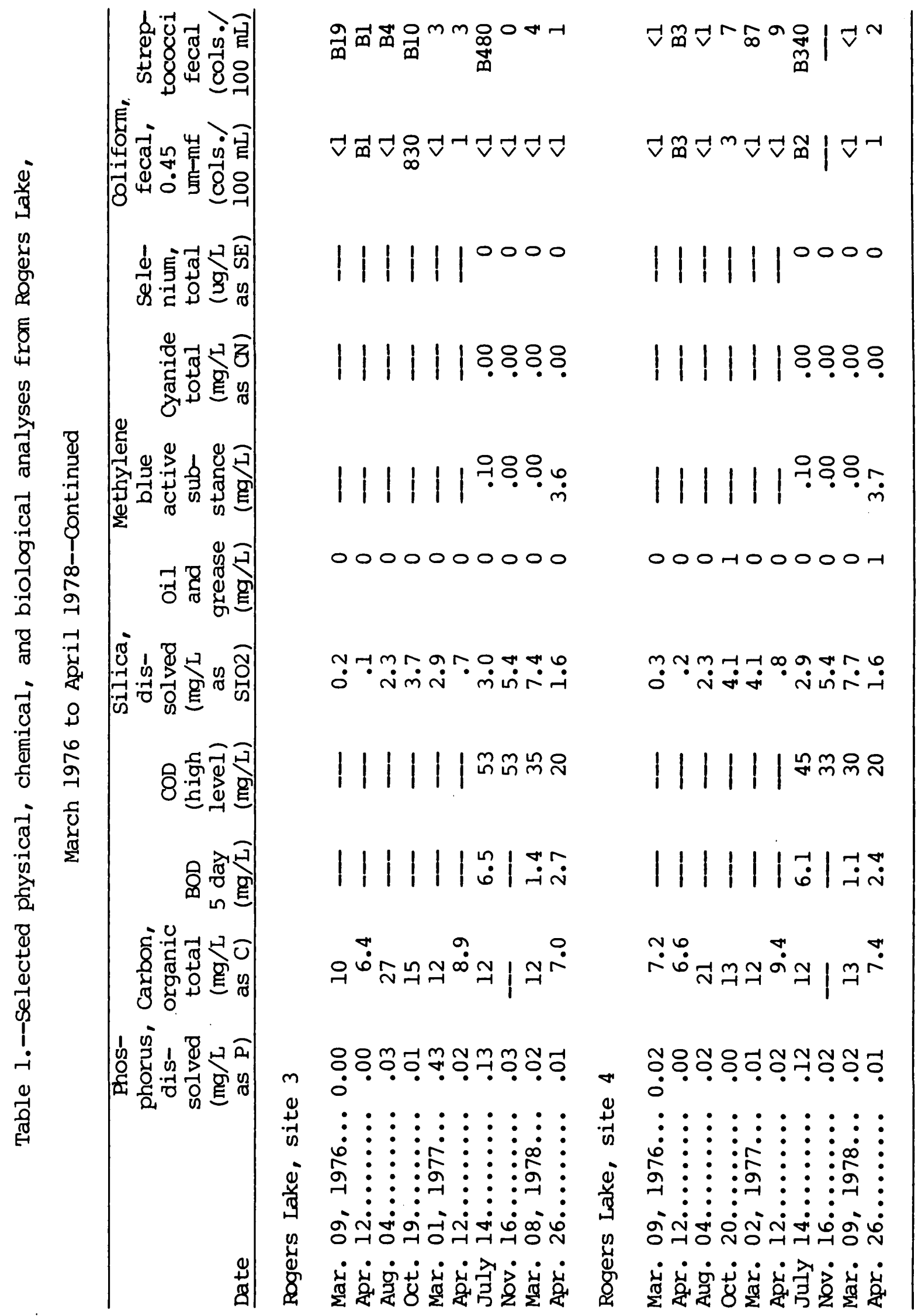




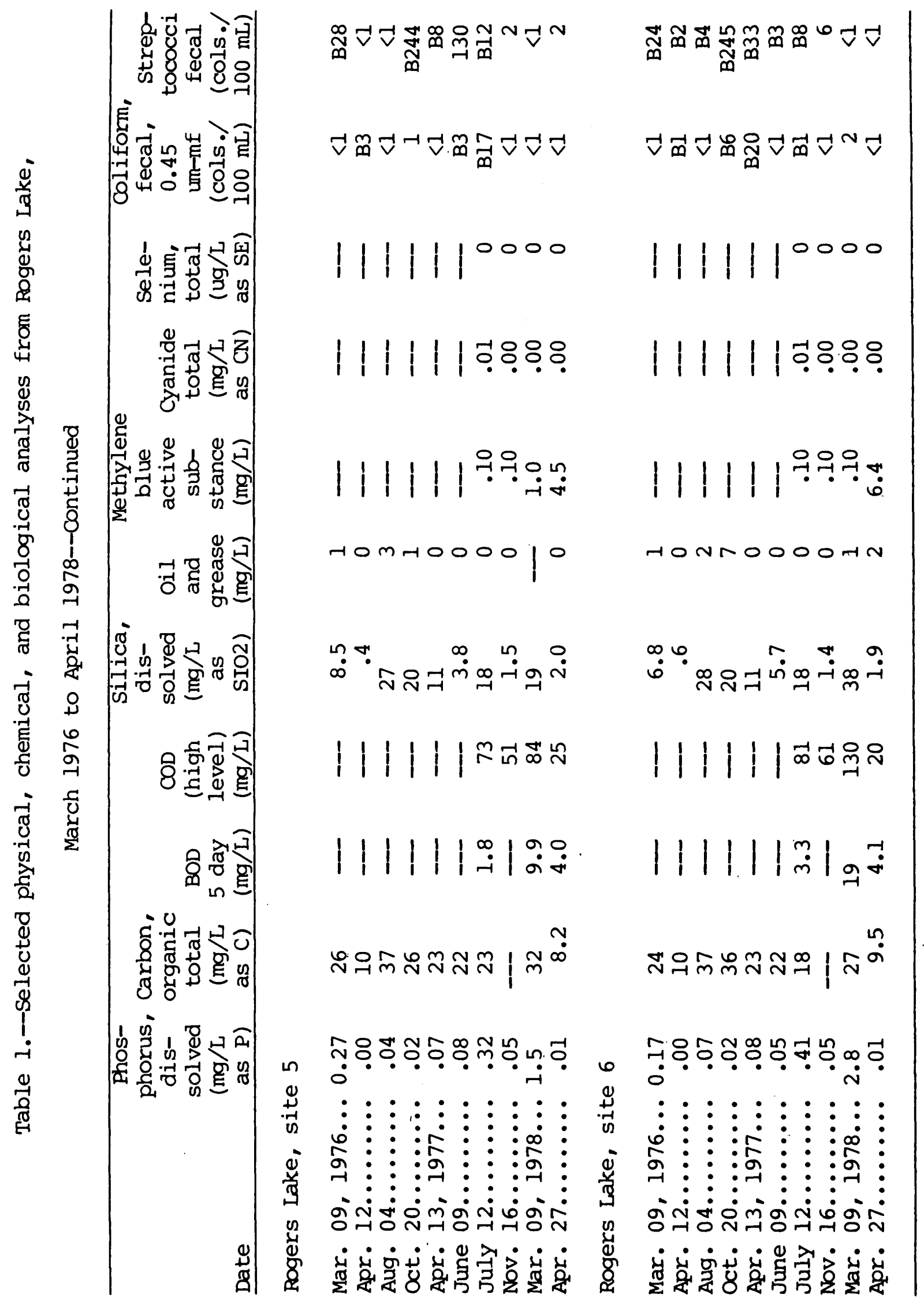


2.5 feet. The lowest conductances and dissolved solids occurred in April 1978 after dilution by melted ice and snow and runoff of precipitation in spring.

The higher mineralization at sites 5 and 6 is clearly shown in table 2 . Average specific conductance and dissolved-solids concentrations are almost two times higher at sites 5 and 6 than in samples from sites in the lower lake. The ranges are also much greater at sites 5 and 6 , mainly resulting from winter conditions.

The mean equivalent proportions of calcium, magnesium, sodium, and chloride for the six sites are shown in table 3. Mean equivalent proportion is the percentage of the total cations or anions represented by a particular cation or anion, calculated through the use of milliequivalents per liter. Sites 5 and 6 have a slightly higher proportion of magnesium and a much lower proportion of calcium than sites 1 to 4 . The difference in calcium may be partly related to the higher organic content and the higher productivity of aquatic plants at sites 5 and 6 . The organic content and productivity of Rogers Lake are discussed in more detail later in the report. Organic substances in water can complex calcium, and biological activity, such as shell construction and plant precipitation of calcium carbonate, tends to decrease the calcium-ion content dissolved in the water (Hutchinson, 1957, p. 664; Reid and Wood, 1976, p. 231). Therefore, even though calcium concentrations are higher in the upper lake, its proportion of the dissolved-solids content is lower.

Table 3 also shows the mean equivalent proportions of sodium and chloride to be higher for sites 5 and 6 . These data tend to support the hypothesis that the upper lake receives runoff that contains road salt.

Chloride concentration increased throughout the open-water period of 1976 as shown by the April, August, and October samples (fig. 3). During 1976, 16.5 inches of precipitation was recorded at the Twin Cities Airport weather station, which was 9.4 inches below normal (National Oceanic and Atmospheric Administration, 1976). Because of the below-normal rainfall in 1976, it was observed that the lake level (that is, lake volume) decreased throughout this period, thereby increasing chloride concentrations.

Due to the low-water levels at the beginning of the 1977 winter sampling period, the chloride concentrations measured in the lower lake in March 1977 were generally higher than those measured in March 1976. The lake was frozen to the bottom at sites 5 and 6 during the March 1977 sampling period, which, of course, prevented sample collection.

During the open-water season of 1977, rainfall was above normal; a total of 34.88 inches of precipitation was recorded for the year (National Oceanic and Atmospheric Administrations, 1977). The dilution effect from this amount of precipitation in 1977 had decreased the chloride concentrations considerably by autumn, as shown by the November 1977 chloride concentration. 
Table 2.--Averages and ranges of specific conductance and dissolved solids for each sampling site at Rogers Lake

Specific conductance, in micromhos per centimeter at $25^{\circ} \mathrm{C}$

\begin{tabular}{|c|c|c|c|c|c|}
\hline Site & $\begin{array}{c}\text { Number } \\
\text { of } \\
\text { samples }\end{array}$ & Average & Range & Average & Range \\
\hline 1 & 10 & 343 & $248-503$ & 213 & $156-319$ \\
\hline 2 & 10 & 304 & $216-424$ & 188 & $129-295$ \\
\hline 3 & 10 & 313 & $262-425$ & 200 & $163-298$ \\
\hline 4 & 10 & 316 & $155-490$ & 195 & $82-298$ \\
\hline 5 & 10 & 560 & $390-1270$ & 380 & $237-823$ \\
\hline 6 & 10 & 577 & $387-1650$ & 378 & $227-1020$ \\
\hline
\end{tabular}


Table 3.-Mean equivalent proportions of calcium, magnesium, sodium, and chloride for each sampling site at Rogers Lake

\begin{tabular}{lllll}
\hline Site & Calcium & Magnesium & Sodium & Chloride \\
\hline 1 & 46 & 31 & 19 & 30 \\
2 & 46 & 32 & 19 & 30 \\
3 & 46 & 31 & 19 & 30 \\
4 & 46 & 32 & 19 & 30 \\
5 & 39 & 35 & 24 & 38 \\
6 & 39 & 35 & 24 & 38 \\
\hline
\end{tabular}




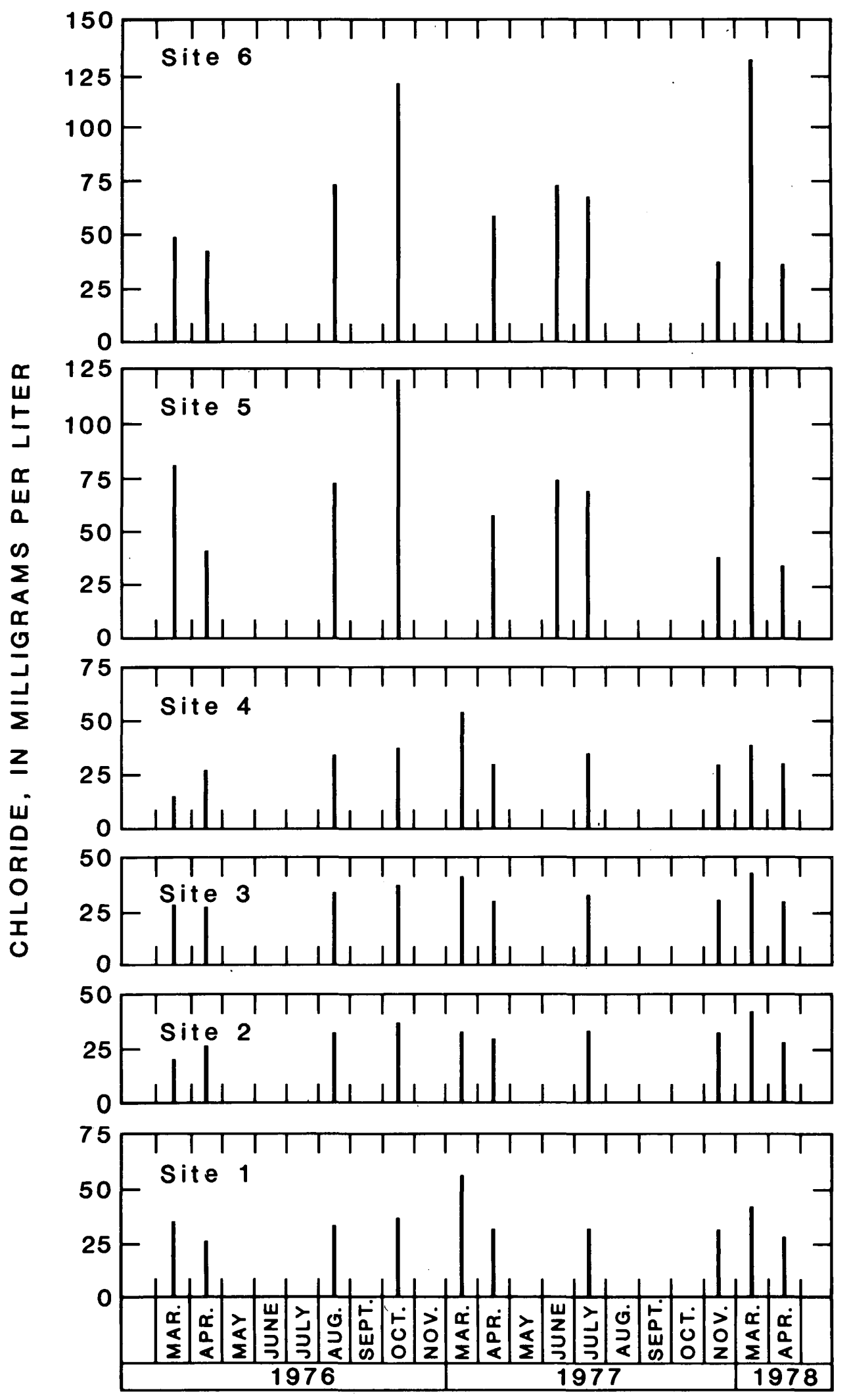

Figure 3.--Chloride concentrations for each sampling site at Rogers Lake 
DO in water is essential for sustaining life. Not only fish and other animal life need oxygen, but plants, which produce oxygen through photosynthesis, need it for respiration.

The amount of DO in eutrophic lakes, such as Rogers Lake, varies widely with time (fig. 4) because of the high production of algae and vascular plants. The lowest DO values for all sampling sites occurred in March 1978 when the lake was frozen. During the ice and snow-cover period, photosynthesis and reaeration are normally at a minimum. Even though respiration and oxidation of organic material continues, DO concentations are generally low. However, relatively high DO concentrations can occur under ice cover. For example, during the March 1977 sampling (table 1) the Do concentration at site 3 was $18.7 \mathrm{mg} / \mathrm{L}$ (139 percent. saturation), the highest DO for site 3. A lack of snow cover on the ice may have permitted sufficient light penetration for significant photosynthesis. The DO produced was trapped and concentrated under the ice. Similar situations of supersaturated conditions under ice are reported by Ficke and Ficke (1977) in their review of the effects of ice on rivers and lakes.

Values of $\mathrm{pH}$ normally increase and decrease with DO concentration as both are related to photosynthesis. Removal of carbon dioxide by photosynthesis causes a decrease of the hydrogen ion concentration or an increase in $\mathrm{pH}$ and an increase in $\mathrm{DO}$ concentration. $\mathrm{pH}$ was lowest under ice during the March 1978 sampling (fig. 4). pH was usually highest in summer, when biological activity was normally at a maximum.

\section{Selected Trace Metals}

Samples of bottom material collected in March and october 1976 and in November 1977 were analyzed for selected trace metals. Water samples collected in October 1976 and November 1977 were analyzed for the same trace metals (tables 4 and 5).

Aluminum and iron were the predominant metals determined in analyses of the bottom-sediment samples. Concentration ranges were 3,300 to 9,600 and 7,900 to $15,000 \mathrm{ug} / \mathrm{g}$ (micrograms per gram), respectively. The metals in the sediment occurred at concentrations comparable with those found in other lakes in the area (Payne, 1977).

Concentrations of trace metals in the water samples collected in october 1976 and November 1977 were low (table 5). The ranges indicated that concentrations of the metals were less than the limits recommended for public water supplies (U.S. Environmental Protection Agency, 1977). Concentrations of most of the metals were slightly higher in October 1976 than in November 1977. Because of the drought in the latter part of 1976, lake volume was smaller when the 1976 samples were collected, thereby concentrating the metals. 
Table 4.--oil and grease, nutrients, and selected trace metals in bottom sediments for each sampling site at Rogers Lake

\begin{tabular}{|c|c|c|c|c|c|c|c|c|c|}
\hline Date & Time & $\begin{array}{l}\text { Organic } \\
\text { carbon } \\
\text { in } \\
\text { bottom } \\
\text { material } \\
(\mathrm{g} / \mathrm{kg})\end{array}$ & $\begin{array}{l}\text { Total } \\
\text { nitro- } \\
\text { gen in } \\
\text { bottom } \\
\text { material } \\
(\mathrm{mg} / \mathrm{kg}) \\
\end{array}$ & $\begin{array}{c}\text { Oil and } \\
\text { grease } \\
\text { in } \\
\text { bottom } \\
\text { material } \\
\text { (mg/kg) }\end{array}$ & $\begin{array}{c}\text { Total } \\
\text { phos- } \\
\text { ohorus in } \\
\text { bottom } \\
\text { material } \\
(\mathrm{mg} / \mathrm{kg})\end{array}$ & $\begin{array}{l}\text { Total } \\
\text { alumi- } \\
\text { num in } \\
\text { bottom } \\
\text { material } \\
(\mathrm{ug} / \mathrm{g})\end{array}$ & $\begin{array}{c}\text { Total } \\
\text { arsenic } \\
\text { in } \\
\text { bottom } \\
\text { material } \\
\text { (ug/g) } \\
\end{array}$ & $\begin{array}{c}\text { Total } \\
\text { barium } \\
\text { in } \\
\text { bottom } \\
\text { material } \\
\text { (ug } / \mathrm{g}) \\
\end{array}$ & $\begin{array}{c}\text { Total } \\
\text { boron } \\
\text { in } \\
\text { bottom } \\
\text { material } \\
\text { (ug/g) }\end{array}$ \\
\hline \multicolumn{10}{|c|}{ Rogers Lake site 1} \\
\hline $\begin{array}{l}\text { Mar., } 1976 \\
09 . . . \\
\text { Oct. 19... } \\
\text { Nov. , } 1977\end{array}$ & $\begin{array}{l}1430 \\
1030\end{array}$ & $\begin{array}{l}112 \\
110\end{array}$ & $\begin{array}{r}3800 \\
11,900\end{array}$ & $\begin{array}{r}0.0 \\
.0\end{array}$ & $\begin{array}{l}210 \\
110\end{array}$ & $\begin{array}{l}9600 \\
5300\end{array}$ & $\begin{array}{l}13 \\
10\end{array}$ & - & $\ddot{--}$ \\
\hline $16 \ldots$ & 1230 & 82 & 201 & .0 & 490 & 4000 & 16 & 80 & 170 \\
\hline \multicolumn{10}{|c|}{ Rogers Lake site 2} \\
\hline $\begin{array}{l}\text { 09... } \\
\text { Oct. 19... } \\
\text { Nov., } 1977\end{array}$ & $\begin{array}{l}1500 \\
1215\end{array}$ & $\begin{array}{l}138 \\
137\end{array}$ & $\begin{array}{r}3000 \\
15,200\end{array}$ & $\begin{array}{r}0.0 \\
.0\end{array}$ & $\begin{array}{l}250 \\
130\end{array}$ & $\begin{array}{l}8500 \\
5100\end{array}$ & $\begin{array}{r}12 \\
8\end{array}$ & - & -- \\
\hline $08 \ldots$ & 1230 & 116 & 36 & .0 & 440 & 5000 & 10 & 100 & 180 \\
\hline \multicolumn{10}{|c|}{ Rogers Lake site 3} \\
\hline $\begin{array}{l}\text { o9... } \\
\text { Oct. 19... } \\
\text { Nov. , } 1977\end{array}$ & $\begin{array}{l}1330 \\
1330\end{array}$ & $\begin{array}{l}111 \\
118\end{array}$ & $\begin{array}{r}2800 \\
13,000\end{array}$ & $\begin{array}{r}0.0 \\
.0\end{array}$ & $\begin{array}{l}420 \\
130\end{array}$ & $\begin{array}{l}8000 \\
4700\end{array}$ & $\begin{array}{r}12 \\
6\end{array}$ & - & $\overline{--}$ \\
\hline $16 \ldots$ & 1330 & 140 & 173 & .0 & 500 & 4900 & 21 & 100 & 450 \\
\hline \multicolumn{10}{|c|}{ Rogers Lake site 4} \\
\hline $\begin{array}{l}09 . . . \\
\text { Oct } 20 . . . \\
\text { Nov. , } 1977\end{array}$ & $\begin{array}{l}1230 \\
0950\end{array}$ & $\begin{array}{l}56 \\
82\end{array}$ & $\begin{array}{l}2400 \\
9900\end{array}$ & $\begin{array}{r}0.0 \\
.0\end{array}$ & $\begin{array}{l}290 \\
150\end{array}$ & $\begin{array}{l}6900 \\
5000\end{array}$ & $\begin{array}{r}10 \\
4\end{array}$ & $\overline{-}$ & - \\
\hline $16 \ldots$ & 1400 & 50 & 76 & .0 & 680 & 3500 & 10 & 90 & 61 \\
\hline \multicolumn{10}{|c|}{ Rogers Lake site 5} \\
\hline $\begin{array}{l}\text { 09... } \\
\text { Oct. 19... } \\
\text { Nov., } 1977\end{array}$ & $\begin{array}{l}0930 \\
1130\end{array}$ & $\begin{array}{l}153 \\
229\end{array}$ & $\begin{array}{r}2900 \\
23,300\end{array}$ & $\overline{0.0}$ & $\begin{array}{l}350 \\
150\end{array}$ & $\begin{array}{l}6600 \\
5000\end{array}$ & $\begin{array}{l}13 \\
14\end{array}$ & - & -- \\
\hline $16 \ldots$ & 1000 & 241 & 277 & .0 & 800 & 3300 & 15 & 120 & 450 \\
\hline \multicolumn{10}{|c|}{ Rogers Lake site 6} \\
\hline $\begin{array}{l}\text { O9.. } \\
\text { Oct. } 20 . . . \\
\text { Nov. , } 1977\end{array}$ & $\begin{array}{l}1030 \\
1145\end{array}$ & $\begin{array}{l}178 \\
243\end{array}$ & $\begin{array}{r}3200 \\
24,300\end{array}$ & $\overline{0.0}$ & $\begin{array}{l}300 \\
160\end{array}$ & $\begin{array}{l}7800 \\
3700\end{array}$ & $\begin{array}{l}18 \\
14\end{array}$ & - & - \\
\hline $16 \ldots$ & 1030 & 251 & 56 & .0 & 310 & 3800 & 8 & 120 & 510 \\
\hline
\end{tabular}


Table 4.--oil and grease, nutrients, and selected trace metals in bottom sediments for each sampling site at Rogers Lake--Continued

\begin{tabular}{|c|c|c|c|c|c|c|c|c|c|}
\hline Date & $\begin{array}{c}\text { Total } \\
\text { cadmium } \\
\text { in } \\
\text { bottom } \\
\text { material } \\
\text { (ug/g) }\end{array}$ & $\begin{array}{c}\text { Total } \\
\text { chrom- } \\
\text { ium in } \\
\text { bottom } \\
\text { materia] } \\
\text { (ug } / g)\end{array}$ & $\begin{array}{c}\text { Total } \\
\text { copper } \\
\text { in } \\
\text { bottom } \\
\text { material } \\
\text { (ug/g) } \\
\end{array}$ & $\begin{array}{c}\text { Total } \\
\text { iron in } \\
\text { bottom } \\
\text { material } \\
(\mathrm{ug} / \mathrm{g}) \\
\end{array}$ & $\begin{array}{c}\text { Total } \\
\text { lead in } \\
\text { bottom } \\
\text { material } \\
\text { (ug/g) }\end{array}$ & $\begin{array}{c}\text { Total } \\
\text { manga- } \\
\text { nese in } \\
\text { bottom } \\
\text { material } \\
(\mathrm{ug} / \mathrm{g})\end{array}$ & $\begin{array}{c}\text { Total } \\
\text { mercury } \\
\text { in } \\
\text { bottom } \\
\text { material } \\
\text { (ug/g) } \\
\end{array}$ & $\begin{array}{c}\text { Total } \\
\text { nickel } \\
\text { in } \\
\text { bottom } \\
\text { material } \\
\text { (ug/g) }\end{array}$ & $\begin{array}{c}\text { Total } \\
\text { zinc in } \\
\text { bottom } \\
\text { material } \\
\text { (ug/g) }\end{array}$ \\
\hline \multicolumn{10}{|c|}{ Rogers Lake site 1} \\
\hline 2 & 26 & 26 & - & 68 & -- & 0.3 & - & 115 & \\
\hline 1 & 15 & 20 & 11,000 & 75 & 240 & .1 & 15 & 80 & \\
\hline 1 & 16 & 19 & 9000 & 70 & 240 & .0 & 15 & 160 & \\
\hline \multicolumn{10}{|c|}{ Rogers Lake site 2} \\
\hline 1 & 25 & 25 & -- & 84 & -- & 0.4 & -- & 166 & \\
\hline 1 & 15 & 24 & 11,000 & 95 & 340 & .1 & 15 & 101 & \\
\hline 1 & 16 & 23 & 9000 & 70 & 320 & .0 & 15 & 74 & \\
\hline \multicolumn{10}{|c|}{ Rogers Lake site 3} \\
\hline 1 & 22 & 25 & - & 90 & - & 0.5 & - & 110 & \\
\hline 1 & 14 & 21 & 10,000 & 80 & 280 & .1 & 15 & 84 & \\
\hline 1 & 44 & 26 & 9000 & 90 & 260 & .0 & 20 & 80 & \\
\hline \multicolumn{10}{|c|}{ Rogers Lake site 4} \\
\hline 1 & 21 & 19 & - & 64 & - & 0.5 & - & 110 & \\
\hline$<1$ & 14 & 22 & 11,000 & 80 & 280 & .2 & 15 & 82 & \\
\hline 1 & 12 & 18 & 7900 & 60 & 240 & .0 & 10 & 56 & \\
\hline \multicolumn{10}{|c|}{ Rogers Lake site 5} \\
\hline 2 & 17 & 25 & - & 80 & -- & 0.7 & - & 94 & \\
\hline 1 & 14 & 22 & 11,000 & 80 & 280 & .8 & 15 & 94 & \\
\hline 1 & 16 & 18 & 9200 & 50 & 640 & - & 15 & 58 & \\
\hline \multicolumn{10}{|c|}{ Augers Lake site 6} \\
\hline 2 & 21 & 32 & -- & 100 & - & 1.0 & - & 175 & \\
\hline 1 & 14 & 24 & 15,000 & 80 & 300 & 1.0 & 20 & 93 & \\
\hline 1 & 36 & 14 & 8900 & 30 & 280 & .1 & 10 & 48 & \\
\hline
\end{tabular}




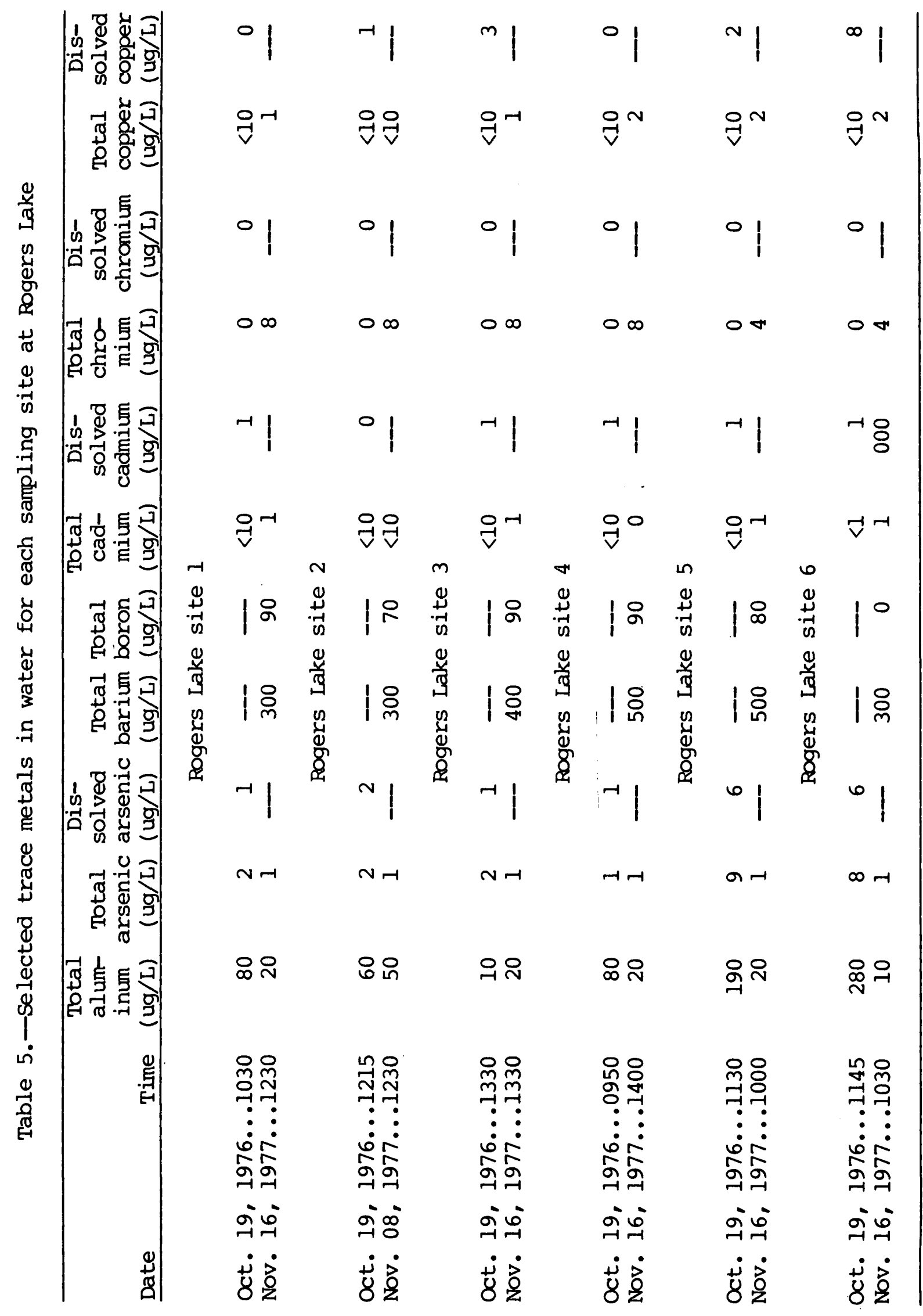




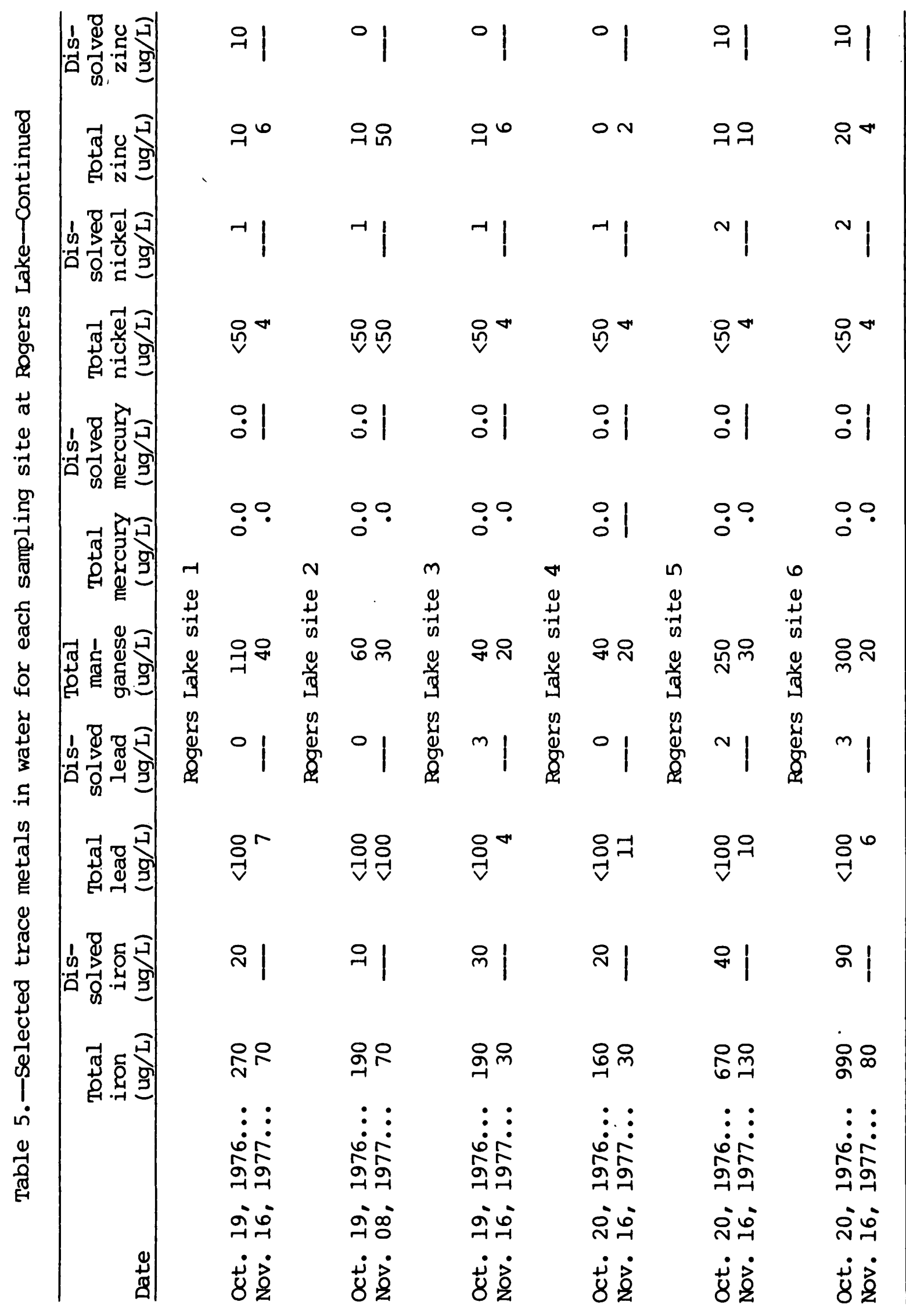



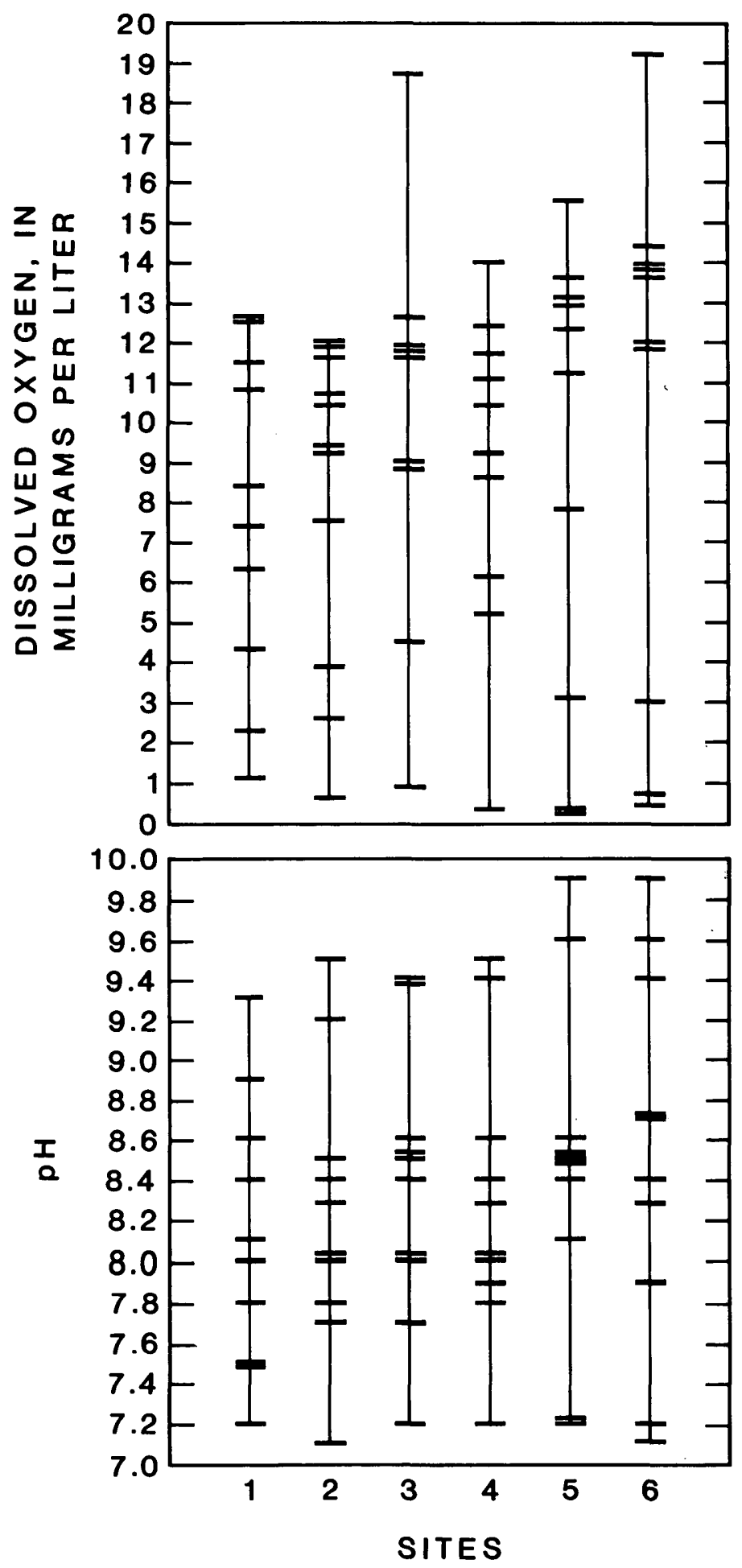

Figure 4.--Dissolved-oxygen concentrations and $p H$ for each sampling site at Rogers Lake. Span indicates range between maximum and minimum values. Each mark across the vertical lines represents a sampled value 
Total concentrations of aluminum, iron, and manganese were much higher at sites 5 and 6 in October 1976 than they were at the other sites. The shallower depths ( $<2 \mathrm{ft}$ ) in the upper lake during that time probably permitted a greater amount of sediment to be stirred up and mixed with the overlying water.

\section{Nutrients}

Nutrients are necessary for growth, repair of tissue, or reproduction of aquatic flora. Nitrogen and phosphorus are considered to be key nutrients required by aquatic flora. Phosphorus is frequently considered to be a limiting factor in phytoplankton production, but Carroll (1962) and Voight (1960) have shown that its concentration in rainfall alone have been more than adequate for supporting algal blooms. The minimum concentrations of nitrogen and phosphorus required for active plant growth (that is, an algal bloom) have not been firmly established; a wide range of minimum requirements is reported in the literature. For example, Greeson and Myers (1969, p. 11-12) list ranges for nitrogen from trace quantities to $5.3 \mathrm{mg} / \mathrm{L}$ and phosphorus from 0.002 to $0.09 \mathrm{mg} / \mathrm{L}$.

Data indicate that Rogers Lake is highly enriched with nitrogen and phosphorus and can support large algal populations. Figure 5 shows the phosphorus concentrations for the six sites.

Phosphorus content at all sites changes concurrently as shown in figure 5. Sites 5 and 6 consistently have the highest concentrations. The dissolved phosphorus values were zero or near zero in many samples collected during the study, which is typical of a eutrophic lake with prolific algal growth.

Phosphorus concentrations in March 1977 at site 3, the deepest part of the lake, were considerably higher than at any of the other sites. A possible explanation for this is that conditions at the water-mud interface produced free phosphorus in excess of the amount utilized by algae. There also were fewer submerged macrophytes utilizing the available phosphorus at site 3.

In July 1977, the dissolved phosphorus concentrations were unusually high at all sites when compared to other open-water sampling periods. The moderately high ammonium-nitrogen concentrations (table 1) suggest that a significant amount of decomposition was taking place, hence, a possible excess of dissolved phosphorus existed at that time. Furthermore, bacteria can convert inorganic phosphates to organic phosphorus that can be released to the water in a form unavailable to plants (Mackenthun and Ingram, 1967, p. 118).

Table 6 shows the average nitrogen, phosphorus, silica, and organic carbon concentrations for all sites. Except for the nitrite plus nitratenitrogen values, concentrations for the rest of the constituents in table 6 were significantly higher at sites 5 and 6 . The Kjeldahl nitrogen, total phosphorus, and total organic carbon reflect, in part, the more intense 


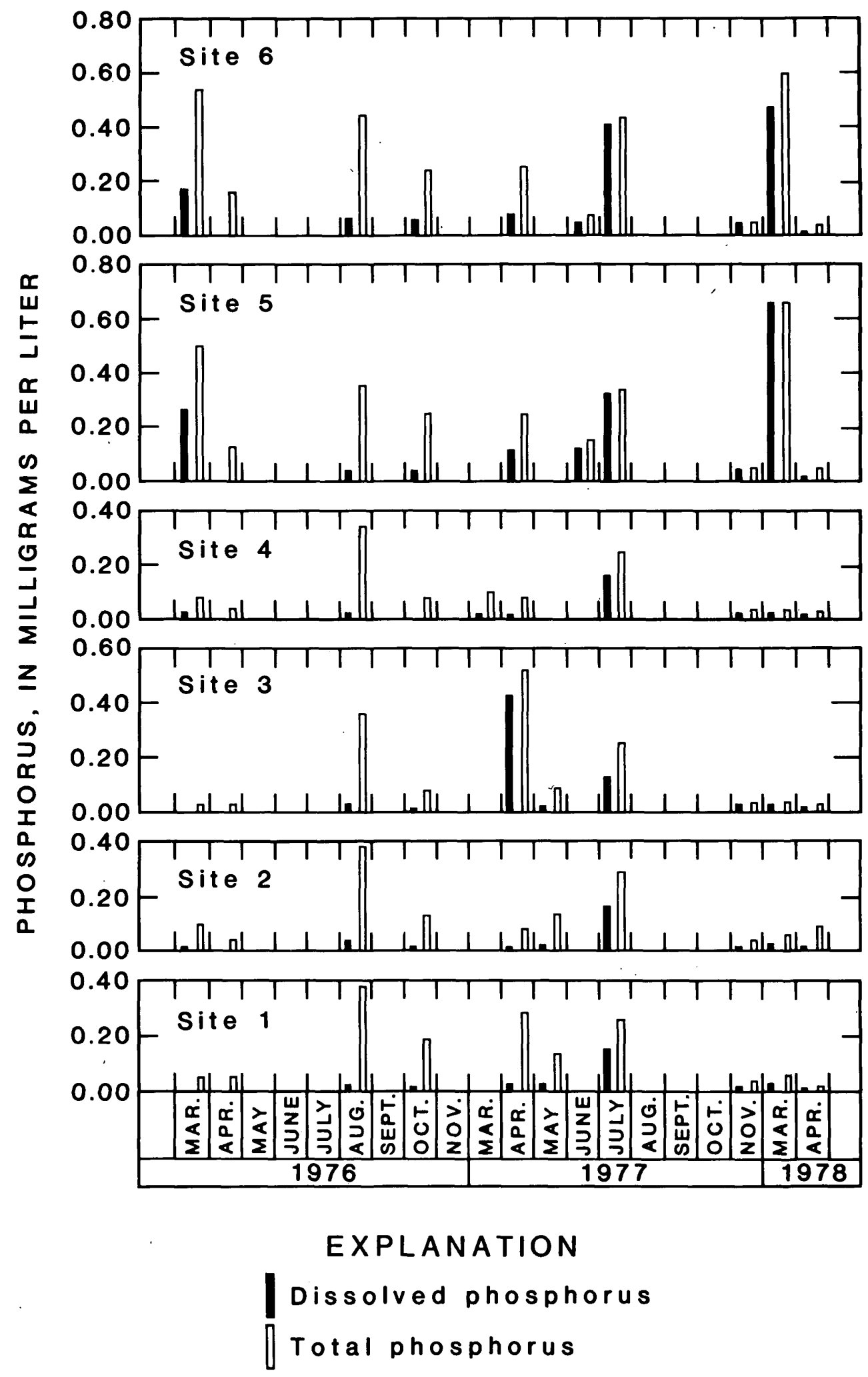

Figure 5.--Total and dissolved-phosphorus concentrations for each sampling site at Rogers Lake 
Table 6.-Average nitrogen, phosphorus, silica, and organic carbon concentrations, in milligrams per liter, for each sampling site at Rogers Lake

\begin{tabular}{cccccccc}
\hline Site & $\begin{array}{c}\text { Total } \\
\text { Kjeldahl } \\
\text { nitrogen }\end{array}$ & $\begin{array}{c}\text { Dissolved } \\
\text { Kjeldahl } \\
\text { nitrogen }\end{array}$ & $\begin{array}{c}\text { Nitrite plus } \\
\text { nitrate- } \\
\text { nitrogen }\end{array}$ & $\begin{array}{c}\text { Total } \\
\text { phosphorus }\end{array}$ & $\begin{array}{c}\text { Dissolved } \\
\text { phosphorus }\end{array}$ & $\begin{array}{c}\text { Silicatal } \\
\text { organic } \\
\text { carbon }\end{array}$ \\
\hline 1 & 2.0 & 1.1 & 0.08 & 0.17 & 0.03 & 2.3 & 15 \\
2 & 1.8 & .88 & .10 & .14 & .03 & 2.4 & 12 \\
3 & 1.8 & 1.0 & .05 & .18 & .08 & 2.3 & 13 \\
4 & 1.7 & .93 & .09 & .11 & .02 & 2.9 & 11 \\
5 & 3.2 & 2.1 & .02 & .36 & .24 & 11 & 23 \\
6 & 3.1 & 1.9 & .02 & .55 & .37 & 13 & 23 \\
\hline
\end{tabular}


biological activity at those two sites. The Kjeldahl nitrogen is largely organic nitrogen. Plants convert inorganic nitrogen (mainly in the form of nitrite plus nitrate-nitrogen) to organic nitrogen in the synthesis of protoplasm, which is reflected in the kjeldahl nitrogen values. Therefore, Kjeldahl nitrogen is an indicator of the flora part of the biomass in a body of water. The phytoplankton concentrations (table 7) confirm that the cell counts were indeed generally higher at sites 5 and 6 . The higher values of most constituents at sites 5 and 6 (table 6 ) also reflect the more pronounced concentration effect from evaporation during the summer months and from ice during the winter months at those shallow-water sites.

Organic carbon, nitrogen, and phosphorus concentrations in bottom sediments at each Rogers Lake site (table 4) are comparable to those found in other shallow eutrophic lakes sampled in Eagan and Apple Valley, Minn., in 1974 (Have, 1975, p. 21-24). These lakes are also in northern Dakota County, and therefore geologic and climatic conditions are similar. Nutrients probably cycle between bottom sediments and the lake water. Mechanical mixing of the bottom sediments by wave action, diving birds, and aquatic rodents recycles nutrients to the water for algal growth. Nutrients are returned to the sediments as algal growth dies off and settles to the lake bottom.

\section{Biological Characteristics}

Blue-green and green algae and diatoms were present in Rogers Lake throughout the year. Blue-green algae were dominant in 66 percent of the samples and had cell concentrations typically in the thousands per milliliter (table 7). Lee (1970) proposed that a concentration of 500 to 1,000 cells per milliliter indicated an excessive amount of phytoplankton production or an algal bloom. The high cell counts are, therefore, characteristic of algal blooms.

Table 8 lists the occurrences of blue-green algae that were dominant in Rogers Lake. Oscillatoria was dominant more frequently at sites 5 and 6 , usually occurring in the winter and autumn. Anacystis was the more frequent in the winter and autumn at sites 1 to 4 . In the spring and summer, the blue-green algae genera were more diverse at all the sites.

Blooms of blue-green algae are particularly obnoxious. The genus Anacystis, which was one of the more frequently occurring genera, has been reported several times as the cause of fatalities among horses, cattle, hogs, sheep, dogs, rabbits, and poultry (Palmer, 1962, p. 53). In their review of algae related toxicity, Ingram and Prescott (1954) found that algae responsible for mammalian, avarian, and fish deaths were all to be found in the blue-green algal group.

In general, the representative genera in Rogers Lake are typical genera found in a highly enriched environment. Palmer (1968) assigned a pollutiontolerant rating to each alga reported by 165 authors in 269 reports. Most of the algae found in Rogers Lake, including the green algae and diatoms, are listed in Palmer's report as being pollution-tolerant genera. 


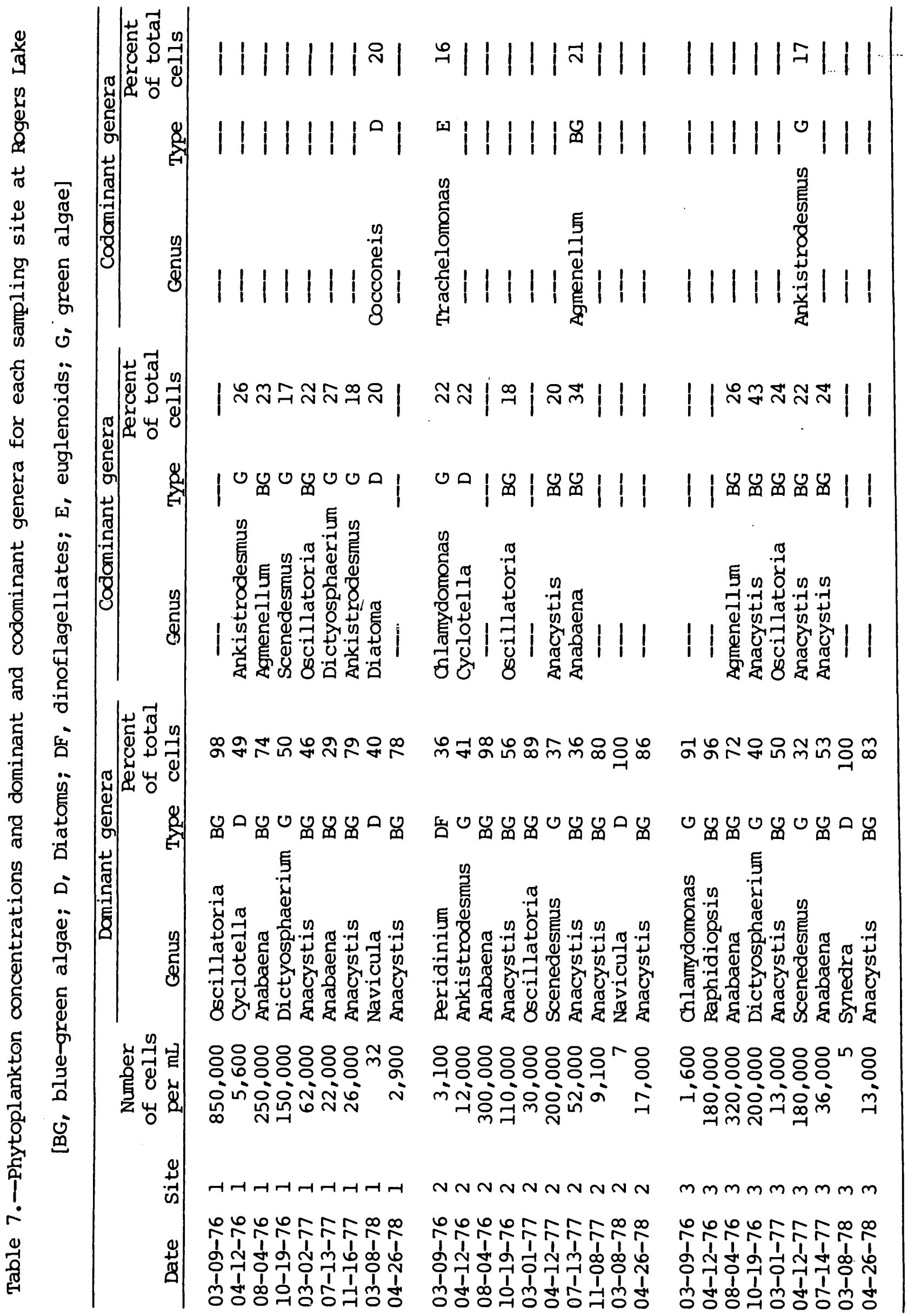




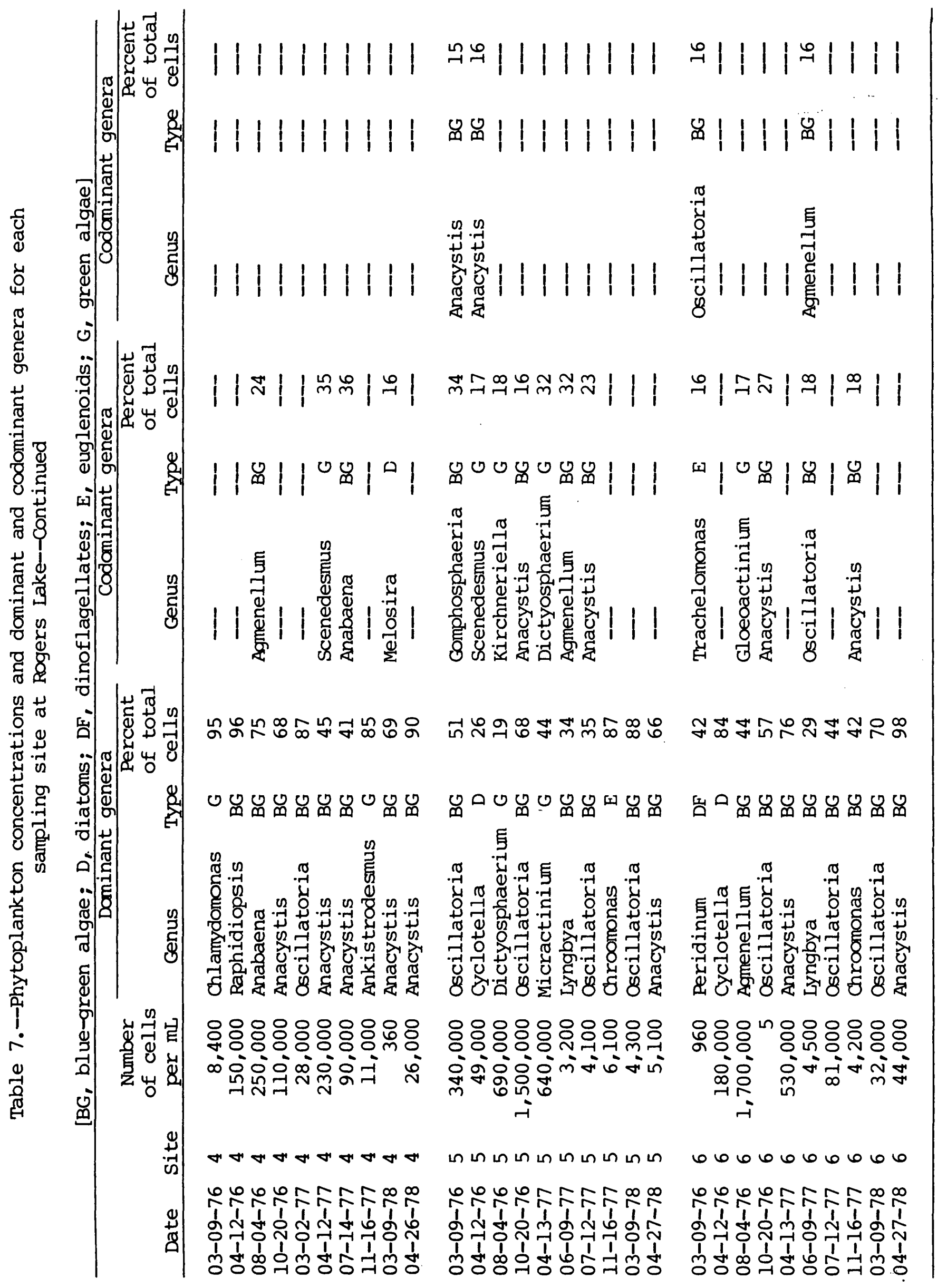


Table 8. -Number of occurrences of blue-green algae for each sampling site at Rogers Lake, March 1976 to April 1978

[Sp-spring, S-summer, A-autumn, W-winter]

\begin{tabular}{|c|c|c|c|c|c|c|}
\hline Site & Oscillatoria & Lyngbya & Anabaena & Anacystis & Raphidiopsis & Agmenellum \\
\hline 1 & 1 & 0 & 2 & 3 & 0 & 0 \\
\hline 2 & 1 & 0 & 1 & 4 & 0 & 0 \\
\hline 3 & 0 & 0 & 2 & 2 & 1 & 0 \\
\hline 4 & 1 & 0 & 1 & 5 & 1 & 0 \\
\hline 5 & 3 & 1 & 0 & 1 & 0 & 0 \\
\hline 6 & 3 & 1 & 0 & 2 & 0 & 1 \\
\hline $\begin{array}{l}\text { Time of } \\
\text { year most } \\
\text { commonly } \\
\text { found }\end{array}$ & st & Sp & $\mathrm{S}$ & $A, W$ & Sp & $S$ \\
\hline
\end{tabular}


Fecal coliform and fecal Streptococci bacteria counts were usually

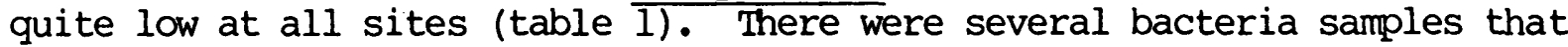
had reported values of less than one colony per 100 milliliters. Only nine samples, or 8 percent, had bacteria counts greater than 100 colonies. The highest fecal coliform count was 830 colonies per 100 milliliters of lake water at site 3 on October 19, 1976. This exceeded the recreational standard of 400 colonies per 100 milliliters at any one time for body-contact recreation (U.S. Environmental Protection Agency, 1977). The highest fecal Streptococci count was 480 colonies per 100 milliliters and also occurred at site 3 on October 19, 1976.

\section{Other 'haracteristics}

Other characteristics tested for in Rogers Lake were Secchi-disk transparency, turbidity, suspended solids, COD, oil and grease, cyanide, and detergents. The determination of some of these characteristics was started later in the study.

Most of the high turbidities, high suspended-solids concentrations, and lowest Secchi-disk transparencies occurred in August 1976 (table 1). Some of the high phytoplankton counts also occurred during this period. In July 1977, however, when phytoplankton counts were much lower, turbidity and suspended solids were lower and light transparencies higher. This suggests that these three physical characteristics are at least partly dependent upon phytoplankton concentrations and that all these characteristics can vary greatly even during the same season.

No significant amounts of oil and grease were detected in the lake water (table 1). Their concentrations ranged from 0 to $7 \mathrm{mg} / \mathrm{L}$. $0 i l$ and grease were detected in 8 of 19 samples at sites 5 and 6 and in 6 of 38 samples at sites 1 through 4. This higher frequency in the upper lake suggests some overland runoff to the lake from State Highway 110. Conceivably, this could happen during heavy rains. No oil and grease were found in the bottom material at any of the sites (table 4 ).

Cyanide, highly toxic to aquatic animals, was detected only at sites 5 and 6 . The concentrations found at both sites were $0.01 \mathrm{mg} / \mathrm{L}$ and can affect the respiratory process of aquatic animals (Minnesota Pollution control Agency, 1978). In the presence of ultraviolet light, sodium ferrocyanide, an anticaking agent used in deicing chemicals, can be reduced to cyanide. Because of the proximity of sites 5 and 6 to State Highway 110 and its intersection with Interstate I-35E, it may be possible that some sodium ferrocyanide is reaching the lake and is being reduced to cyanide.

COD is a measure of the quantity of oxidizable compounds (mainly organic) present in water. Like TOC (total organic carbon) it would partly reflect the degree of: biomass, which is mostly organic. COD concentrations were much higher at sites 5 and 6 than at sites 1 to 4 (table 3). The average COD concentrations $f \cdot r$ sites 1 to 6 are 38, 37, 40,32, 58, and 73 $\mathrm{mg} / \mathrm{L}$, respectively. 


\section{SUMMARY}

Selected physical, chemical, and biological characteristics were determined to assess the quality of Rogers Lake. These data will serve as baseline information to detect and evaluate water-quality changes during highway construction.

Rogers Lake is divided by a county road. The upper lake has less area and depth than the lower lake. A golf course surrounds much of the upper lake and a four-lane highway lies near its north end. These characteristics contribute to the difference in chemical and biological quality between the upper and lower lakes. The lower lake has more residential development, an inlet for storm sewers, and an outlet for overflow.

Rogers Lake had relatively high concentrations of sodium and chloride compared with many other lakes in the area. The sodium and chloride values ranged from 7.2 to 55 and 15 to $130 \mathrm{mg} / \mathrm{L}$, respectively, with the upper lake having higher concentrations than the lower lake. A possible major source of the sodium and chloride is State Highway 110 north of the upper lake. This source, together with the smaller volume of water in the upper lake, resulted in the relatively high concentrations.

The upper lake also contained greater concentrations of many other compounds. For example, total nitrogen and phosphorus were higher in the upper lake. Fertilization and irrigation of the golf course may have contributed part of the nutrient load to the upper lake.

Both the upper and lower lakes were eutrophic and were mainly dominated by blue-green algae year around. The highest cell counts occurred in the upper lake. 


\section{REFERENCES}

American Public Health Association, American Water Works Association, and Water Pollution Control Federation, 1971, Standard methods for the examination of water and wastewater (13th ed.): New York, American Public Health Association., $874 \mathrm{p}$.

Bray, Edumnd C., 1977, Billions of years in Minnesota: St. Paul, Minnesota, North Central Publication Company, $102 \mathrm{p}$.

Brown, E., Skougstad, M. W., and Fishman, M. J., 1970, Methods for collection and analysis of water samples for dissolved minerals and gases: U.S. Geological Survey Techniques of Water-Resources Investigations, Book 5, Chapter Al, 160 p.

Carroll, D., 1962, Rainwater as a chemical agent of geological processes--a review: U.S. Geological Survey Water-Supply Paper 1535-G, 18 p.

Ficke, Eleanore R., and Ficke, John F., 1977, Ice on rivers and lakes--a bibliographic essay: U.S. Geological Survey Water-Resources Investigations 77-95, $173 \mathrm{p}$.

Goerlitz, D. F., and Brown, E., 1972, Methods for analysis of organic substances in water: U.S. Geological Survey Techniques of Water-Resources Investigations, Book 5, Chapter A3, $40 \mathrm{p}$.

Greeson, P. E., 1969, Lake eutrophication--a natural process: Water Resources Bulletin, v. 5, no. 4, p. 16-30.

Greeson, P. E., Ehlke, T. A., Irwin, G. A., Lium, B. W., and Slack, K. V., 1977, Methods for collection and analysis of aquatic biological and microbiological samples: U.S. Geological Survey Techniques Water-Resources Investigations, Book 5, Chapter A4, 332 p.

Greeson, P. E., and Myers, G. S., 1969, The limnology of Oneida Lake, ar. interim report: New York State Conservation Department, Water Resources Commission, Report of Investigations, R I-8, p. 11-12.

Have, M. R., 1975, Some limnological aspects of 20 selected lakes in Eagan and Apple Valley, Minnesota: U.S. Geological Survey open-file Report 75-528, $44 \mathrm{p}$.

Hem, J. D., 1959, Study and interpretation of the chemical characteristics of natural water: U.S. Geological Survey Water-Supply Paper 1473, $269 \mathrm{p}$.

Hutchinson, G., 1957, A treatise on limnology, geography, physics, and chemistry; vol. 1, New York, John Wiley and Sons, Inc., 1015 p.

Ingram, W. M., and Prescott, G. W., 1954, Toxic fresh-water algae: The American Midland Naturalist, v. 52, no. 1., p. 75-87. 


\section{REFERENCES}

Lee, F. G., 1970, Eutrophication: Wisconsin University, Resources Center, Occasional Paper no. 2, 39 p.

Mackenthun, K. M., and Ingram, W. M., 1967, Biological associated problems in freshwater environments: U.S. Federal Water Pollution Control Administration, $287 \mathrm{p}$.

Minnesota Pollution Control Agency, 1978, Highway de-icing chemicals: Minnesota Pollution Control Agency, Division Water Quality, Planning section package 1 supplement, $125 \mathrm{p}$.

National Oceanic and Atmospheric Administration, 1976, Hourly precipitation data annual summary--Minnesota 1976: Asheville, North Carolina, National Climatic Center, v. 26, no. 13, 6 p.

1977, Climatological data annual summary-Minnesota 1977: Asheville, North Carolina, National Climatic Center, v. 83, no. 13, 15 p.

Palmer, C. M., 1962, Algae in water supplies: U.S. Department Health, Education, and Welfare, $88 \mathrm{p}$.

1968, A composite rating of algae tolerating organic pollution:

Presented at symposium sponsored by Phycological society America and Phycological Section Botony Society America, p. 26-30.

Payne, G. A., 1977, Baseline water quality of Long Meadow Lake, Ponds AP-9 and AP-10 and Black Dog Creek, Hennepin and Dakota Counties, Minnesota: U.S. Geological Survey Open-file Report 77-424, 56 p.

Reid, G. K., and Wood, R. D., 1976, Ecology of inland waters and estuaries: New York, D. Von Nordstrand Company, $485 \mathrm{p}$.

U.S. Environmental Protection Agency, 1977, Quality criteria for water: Washington, D. C., U.S. Environmental Protection Agency, 256 p.

Voight, G. H., 1960, Alteration of the composition of rainwater by trees: American Midland Naturalist, v. 63, p. 321-329. 